Federal Reserve Bank of Minneapolis

Research Department Staff Report 486

Revised February 2015

\title{
Quid Pro Quo: Technology Capital Transfers for Market Access in China*
}

Thomas J. Holmes

University of Minnesota

and Federal Reserve Bank of Minneapolis

Ellen R. McGrattan

University of Minnesota

and Federal Reserve Bank of Minneapolis

Edward C. Prescott

Arizona State University

and Federal Reserve Bank of Minneapolis

\begin{abstract}
By the 1970s, quid pro quo policy, which requires multinational firms to transfer technology in return for market access, had become a common practice in many developing countries. While many countries have subsequently liberalized quid pro quo requirements, China continues to follow the policy. In this paper, we incorporate quid pro quo policy into a multicountry dynamic general equilibrium model, using microevidence from Chinese patents to motivate key assumptions about the terms of the technology transfer deals and macroevidence on China's inward foreign direct investment (FDI) to estimate key model parameters. We then use the model to quantify the impact of China's quid pro quo policy and show that it has had a significant impact on global innovation and welfare.
\end{abstract}

Keywords: Quid Pro Quo, China, FDI

JEL classification: F23, F41, O33, O34

* Corresponding author: McGrattan, Department of Economics, University of Minnesota, Minneapolis, MN 55455, phone: 612-625-6714, fax: 612-624-0209, email: erm@umn.edu. This paper is a major revision of an earlier draft entitled "Technology Capital Transfer." All materials, including the data on all Chinese patents, are available at www.minneapolisfed.org/research/sr/sr486.html. We thank Andy Atkeson, Dave Backus, Nick Bloom, Ariel Burstein, Galina Hale, Patrick Kehoe, Peter Klenow, Sam Kortum, Finn Kydland, Robert Lucas, Monika Piazzesi, Natalia Ramondo, Veronica Rappaport, Kim Ruhl, Martin Schneider, Kjetil Storesletten, Michèle Tertilt, Fabrizio Zilibotti, four anonymous referees, and seminar participants at Arizona State University, the Econometric Society, the Federal Reserve Bank of Atlanta, the Federal Reserve Bank of Minneapolis, the Federal Reserve Bank of St. Louis, the National Bureau of Economic Research, Simon Fraser University, the Society for Economic Dynamics, Stanford, Sveriges Riksbank, University of British Columbia, University College London, University of Santa Barbara, University of Washington, and Universidad Torcuato Di Tella for helpful comments on earlier drafts of the paper. We also thank Andrea Waddle for research assistance, Joan Gieseke for editorial assistance, and Jing Fang for help with the Chinese patent data. The views expressed herein are those of the authors and not necessarily those of the Federal Reserve Bank of Minneapolis or the Federal Reserve System. 


\section{Introduction}

Debates have long been waged over appropriate policies for the encouragement of technology transfer to developing countries (see UNCTAD, 2001). By the 1970s, quid pro quo policy, which requires multinational firms to transfer technology in return for market access, had become a common practice in many developing countries. While many countries have subsequently liberalized quid pro quo requirements, China continues to follow the policy. In this paper, we incorporate quid pro quo policy into a multicountry dynamic general equilibrium model, using microevidence from Chinese patents to motivate key assumptions about the terms of the technology transfer deals and macroevidence on China's inward foreign direct investment (FDI) to estimate key model parameters. We then use the model to quantify the impact of China's quid pro quo policy and show that it has had a significant impact on global innovation and welfare.

The model is an extension of the multicountry dynamic general equilibrium model of FDI developed in McGrattan and Prescott $(2009,2010)$. The key concept of the framework is technology capital, which is nonrivalrous capital that can be used across locations. Examples of technology capital include accumulated know-how from investments in R\&D and brands. Once a firm makes an investment in technology capital in its home country, it can utilize the capital in other markets around the world as foreign countries open up to FDI. In addition to extending the McGrattan and Prescott model by incorporating quid pro quo, we also introduce an intensity margin that allows foreign firms to choose how much technology capital to bring into host countries. The fact that quid pro quo acts like a tax induces foreign firms to hold back on the level of technology capital they deploy in a host country. Furthermore, once technology capital is transferred, investments necessary to exploit the technology are measured as domestic investment rather than as FDI.

Consistent with our theory, relatively little of China's inward FDI comes from advanced economies that do the vast majority of the world's R\&D, that is, from the United States, Western Europe, and Japan. For example, Branstetter and Foley (2010) show that FDI flows from the United States into China are small relative to flows of U.S. FDI to other destination countries, as well as relative to FDI flows from other source countries into China. ${ }^{1}$ In fact, even as China has risen and its demand for advanced products like automobiles has exploded, the share of FDI inflows into China from advanced economies (again, the United States, Western Europe, and Japan) has actually decreased significantly, as Figure 1 illustrates for the period 1990-2010. ${ }^{2}$

A key assumption of our theory, based on microevidence from Chinese patent applications, is that the property rights being exchanged apply in China, not outside; for example, the joint venture Shanghai GM can sell Chevrolets and Buicks in China, but not in the United States. An important

1 See also Prasad and Wei (2007) and UNCTAD (2014).

2 As explained below, we combine flows for mainland China, Hong Kong, Taiwan, and Macao-netting out intraprovincial flows - and refer to the combined economic region as China. We also exclude flows from the tax havens such as the British Virgin Islands (BVI) and the Cayman Islands. 
implication of this assumption is that even as China develops and accumulates significant property rights to technology capital in China, FDI outflows from China to the advanced economies will remain low. After 1985, an explosion in patenting took place in China. Prior to 1985, the patent system did not even exist, but its scale is now comparable to the systems in the United States, Europe, and Japan. ${ }^{3}$ Indeed, in a single decade, from 2000 to 2010, the domestic share of published patents in China increased from 37 percent to 73 percent. Yet, despite this explosion in Chinese patenting, FDI outflows from China to the advanced economies continue to be relatively small when compared with countries doing significant R\&D, consistent with our theory (see Figure 2).

To understand the economic effects of quid pro quo, a useful approach is to compare and contrast quid pro quo policy with a tax imposed by a host country on FDI profits. Both distort investment decisions, and both entail a payment by foreign firms to the host government — payment in cash in the case of a tax on profits and payment with technology capital in the case of quid pro quo. The key difference lies in what happens after payment. With a tax, foreign firms continue to own and manage the technology, whereas with quid pro quo requirements, management is reallocated to domestic firms, and this result can have significant effects on productivity. In particular, domestic management need not confront the barriers to investment that foreign firms face, which implies a productivity gain, in part because the transferred technology is no longer subject to further quid pro quo and the distortions that accompany it. This productivity gain may potentially be offset by a loss in effective management of the technology when it is transferred from the foreign to the domestic firms. We allow for such a loss in our analysis.

We use our quantitative model to conduct welfare analysis and to estimate the extent of technology transfer in China over the period 1990-2010. The model has six economies, namely, China, the United States, Western Europe, Japan, an entity comprising Brazil, Russia, and India, referred to as BRI, and the rest of the world. Key model parameters include those that determine the quid pro quo policy that the advanced economies face, country-level policy parameters that govern overall openness to FDI, and country-level total factor productivity (TFP). We select parameters to align the model and the data over the period 1990-2010 with respect to relative FDI inflows into China by the advanced economies, overall FDI inflows into each country, and relative GDP levels of each country. We then simulate the economy with quid pro quo policies as observed and a counterfactual with China abandoning quid pro quo starting in 1991. A key result is that the advanced economies lose the equivalent of about 0.3 to 0.5 percent in consumption because of China's quid pro quo. China is now large enough that its policies materially affect the welfare of the advanced economies and the incentives for multinational firms to create technology capital. On the other

\footnotetext{
3 In 2011, the patent office in China granted 172,000 patents, compared with 225,000, 98,000, and 238,000 patents granted by the offices in the United States, Europe, and Japan (the Europe statistic combines the European patent office with the offices in Germany, Italy, France, and the United Kingdom). See World Intellectual Property Organization (WIPO, 2012)
} 
hand, China benefits significantly from the policy, with a gain in consumption of nearly 5 percent. Indeed, China benefits from quid pro quo so much that it would choose to follow this policy even if other countries choose to follow it as well. In contrast, the United States and Western Europe are left worse off in a world in which all countries follow quid pro quo, compared with a world where no countries follow it. In addition to the effects on consumption, quid pro quo leads to a significant increase in the fraction of technology capital used in China that is transferred to China. Thus, the quid pro quo policy is both welfare enhancing and fulfills the Chinese government's goal of having indigenous innovation. ${ }^{4}$

Ample evidence supports the key mechanisms of the model. Prior to 2001, when China joined the World Trade Organization (WTO), quid pro quo transfer of technology was explicit Chinese policy. Since then, the policy has become implicit and is accomplished through requirements such as joint ventures. Surveys of multinationals (cited below) confirm that quid pro quo is an implicit policy, and a majority of survey respondents say that policy requirements are increasing over time. Furthermore, microevidence from patent data supports the key assumption of the model that transferred property rights apply inside China, not outside. We construct a unique data set of Chinese patents - with foreign and domestic patents separately catalogued - and we use it to determine which patents go outside of China in the form of patents in other countries. We focus in particular on patents in China that are jointly owned by a foreign multinational and a local Chinese partner. These patents come out of the various joint ventures that foreign firms have been forced into as a requirement for obtaining market access. They are direct evidence of technology connections between foreign and domestic firms and direct evidence of Chinese firms obtaining property rights in China. We document a distinct empirical finding about these jointly owned patents: the property rights of the Chinese partners stop at the border. Specifically, we find that jointly owned Chinese patents tend not to link to patent applications in foreign countries. In cases in which such a link does exist outside, only the foreign partner's name is on the application; the Chinese partner's name is dropped. An interesting example in our data set is the case of the joint venture between the foreign telecommunications giant Alcatel-Lucent and the domestic firm Shanghai Bell. Through 2010, 97 of the jointly owned patents in China have gone outside in the form of WIPO applications. Yet, in all but five cases, the applications explicitly state that Shanghai Bell ownership applies only in China, whereas Alcatel-Lucent ownership applies in China and everywhere else.

Among developing countries, significant precedent exists for policies that promote technology transfer from foreign to domestic firms. In the postwar period, Japan, and then Korea, pursued

\footnotetext{
4 The plan, which is laid out in China State Council (2006), states China's goal for zizhu chuangxin; zizhu means "indigenous" or "self-owned," and chuangxin means "innovation." See the discussion in USITC (2010).
} 
policies that limited FDI inflows. ${ }^{5}$ Technology from foreign firms generally came in through licensing deals with domestic firms. ${ }^{6}$ A situation in which domestic firms first license a technology, and then imitate that technology, is quid pro quo of sorts, albeit one that does not show up in FDI flows. But many examples can be found of countries adopting policies to regulate FDI. For example, in the 1970s, India, Brazil, the Philippines, Mexico, and the Andean Community, comprising the South American countries of Bolivia, Colombia, Ecuador, and Peru (known as the Andean Pact until 1996), variously imposed joint venture requirements with local partners, government reviews of all contracts, and limits on the ability of foreign firms to write contracts that would preserve firms' ownership of technology capital. ${ }^{7}$ In fact, in the $1980 \mathrm{~s}$, a number of developing countries worked within the United Nations to implement an international agreement that would facilitate use of quid pro quo under international law. ${ }^{8}$ Although that initiative was ultimately unsuccessful, technology transfer continues to be a fault line in international negotiations between developed and developing countries. The WTO website notes that "developing countries in particular, see technology transfer as part of the bargain in which they have agreed to protect intellectual property rights," referring to the Trade-Related Aspects of Intellectual Property Rights (TRIPS) agreement on intellectual property. ${ }^{9}$ That is, in a broad sense, technology transfer is quid pro quo for developed countries to earn rents on their technology capital in developing countries.

The rest of the paper is organized as follows. Section 2 discusses the related literature. Section 3 presents evidence in support of the key mechanisms in our model. Section 4 describes our multicountry general equilibrium model. Section 5 explains how the model parameters are pinned down by the data. Section 6 conducts policy analysis. Section 7 discusses robustness, and Section 8 concludes.

\section{Related Literature}

Much of the literature on FDI focuses on the margin of whether a particular firm sells in a foreign market through exports or by setting up a foreign affiliate (see Horstmann and Markusen, 1992;

5 For a discussion of an "elaborate control system...designed to filter out most inflows of FDI" in Japan, see Mason (1992, p. 151). For a discussion on Korea, see Kim and Hwang (2000).

6 For U.S. firms, there was "one real 'option' to participate in the postwar economy: license technology to a Japanese firm" (Mason, 1992, p. 151). See also Montalvo and Yafeh (1994). For some discussion of Korea, see Chapter 7 of Moran (1999), "FDI and Technology-Licensing Requirements."

7 See McCulloch (1981) for a discussion. Banned provisions included "grant back" clauses that made technological improvements arising through a joint venture the property of the foreign partner. See Barnes (1979) and UNCTAD (2003). Some of these policies have persisted. Brazil, for example, continues to review technology transfer agreements and ban such clauses. See WIPO (2013).

8 See the 1985 Draft International Code of Conduct on the Transfer of Technology, as published in UNCTAD (1996), and see UNCTAD (2001) for discussion.

9 See World Trade Organization, TRIPS material, http://www.wto.org/english/tratop_e/trips_e/techtransfer_e. htm, accessed July 23, 2014. 
Markusen and Venables, 2000; Helpman, Melitz, and Yeaple, 2004; and Ramondo and RodríguezClare, 2013). Taking into account that consumption goods come in different varieties is essential to these analyses because this differentiation motivates exports and imports of goods between countries - that is, wool for wine. In contrast, our model has only a single consumption good, and the main force for aggregate trade flows is imperfectly correlated total factor productivities (as in Backus, Kehoe, and Kydland, 1992). Our emphasis is on companies using FDI to sell to local consumers, not as an export base. Each unit of technology capital has a potential use in production at each location; to realize the potential use, the capital must be deployed locally. Although in general there are important connections between FDI and trade, we believe that abstracting from trade in differentiated consumption goods in the context of this study is useful for two main reasons. First, the entry regulations for selling in the domestic market (ordinary trade) are more stringent - and quid pro quo policy has more bite here - than the regulations for selling only in export markets (processing trade). ${ }^{10}$ These differences are not surprising because the Chinese government has a monopoly over access to its domestic market, whereas it might face competition with other countries to be an export base to other markets. Second, FDI aimed at the local market is a significant component of the FDI going into China. ${ }^{11}$ For example, the automobile industry is one of the major industries with inflows into China from the United States, Europe, and Japan. The joint ventures that are set up as part of these inflows sell primarily to the domestic market.

Our model of multinational firms puts the Arrow-Debreu structure of perfect competition to work in analyzing foreign direct investment. The curvature in a firm's problem comes from increasing marginal cost as marginal revenue is constant. It is more common in the international economics literature to employ monopolistic competition, where the curvature in a firm's problem comes from decreasing marginal revenue as marginal cost is constant (see, for example, Helpman Melitz, and Yeaple, 2004). The motivation for our choice is that the competitive framework builds on an extensive body of work in macroeconomics that has shown conformity of aggregate predictions with data from the national and international accounts. ${ }^{12}$ We suspect, however, that our results would be very similar if we extended the framework to allow for increasing returns and monopolistic competition.

One example from the literature that takes a quantitative theoretical approach, as we do here, is the model of international technology diffusion in Eaton and Kortum (1999). The authors trace how ideas patented in one country diffuse abroad as patents in other countries. Our analysis of

10 For example, in 1986 China adopted a policy in which foreign firms selling only to export markets could enter as a wholly foreign-owned enterprise, rather than through a forced joint venture. See Branstetter and Lardy (2006).

11 See Branstetter and Foley (2010) and Defever and Riaño (2012), who show that most of the foreign firms that use China as an export base are from Taiwan and Hong Kong.

12 See, for example, Burstein and Monge-Naranjo (2009), McGrattan and Prescott (2010), and Ramondo (2014). 
whether Chinese patents go outside of China is in keeping with the spirit of their work. Our work differs from theirs, however, in at least four ways. First, although their structure allows for imitation, it does not incorporate the quid quo pro mechanism that is central here. Second, we focus on the transition dynamics of knowledge transfer between developed countries and developing countries, such as the United States and China, whereas Eaton and Kortum (1999) explore a steady-state relationship between developed countries, such as the United States and Germany. Third, in addition to looking at patent statistics, we focus on data on FDI flows. Fourth, our modeling environment with perfectly competitive firms is different from the structure of Bertrand oligopoly they use (which is based on Grossman and Helpman, 1991a), but we acknowledge that our aggregate approach leaves out potentially interesting strategic interactions at the microlevel from head-to-head competition between a small number of competitors. ${ }^{13}$

An earlier literature emphasizes the trade-off between the benefits of greater FDI and the costs of diminishing the value of intellectual property holdings. Theoretical contributions to this literature include Grossman and Helpman (1991b) and Helpman (1993), who study growth models with two regions - North and South - with the South imitating products from the North. Lai (1998) extends these models to allow the degree of imitation to be a function of whether the firm engages in FDI in the South (see also Markusen, 2001). In these papers, the benefit to the North is lower production costs, which is different from the benefit of market access that we focus on here. Also, some empirical work finds that imitation is a deterrent to FDI. For example, Branstetter et al. (2011) present regression evidence that multinational companies increase their FDI after host nations strengthen their intellectual property protection.

This paper highlights the relatively low investment flows between China and the technologically advanced economies and, in particular, the fact that the share of flows from advanced countries have been falling in recent years. An existing literature considers frictions that limit FDI flows between pairs of countries due to characteristics specific to the pair, such as differences in language and geographic distance. (Recent examples are Keller and Yeaple, 2013, and Ramondo and RodríguezClare, 2013.) In our robustness analysis, we consider a version of the model without quid pro quo but include an additional friction that limits FDI flows between countries in the West, such as the United States and Western Europe, and countries in the East, such as China. The friction depresses the levels of inflows and outflows. Since frictions like language differences and geographic distance are constant over time, however, this alternative model without quid pro quo cannot account for why the share of inward FDI from advanced countries is falling over time.

Fajgelbaum, Grossman, and Helpman (2014) propose the Linder hypothesis as an alternative explanation for the relatively low investment flows between China and the technologically advanced

13 For example, a Bertrand oligopoly approach would set up a "prisoner's dilemma"-like game between foreign firms. Firms might gain from holding back technology cooperatively. However, China might play them off against each other and get technology transfer in equilibrium. 
economies, but this theory also has counterfactual predictions for the time paths of FDI flows. The idea behind the Linder hypothesis is that countries with similar incomes are more likely to be FDI partners, as compared with countries with different incomes, because they share similar consumption patterns. For example, a rich country like Germany will tend to make luxury carssuch as BMWs and Mercedes - which are sold by their affiliates in rich countries like the United States, rather than in poor countries like India where the world's lowest-priced car is made (the $\$ 3,000$ Tata Nano). In the theory, differences in income turn out to be similar to differences in language and geographic distance in creating effective barriers to FDI flows. If we apply the Linder hypothesis to the case of FDI between China and the advanced economies, we find that it implies counterfactually that the relative share of FDI inflows from the advanced (rich) countries into China should be increasing as China moves up the income ladder, contrary to what we see in the data.

Finally, although we use theory to indirectly measure investments that are not counted in China's national accounts, such as R\&D and investment in brands, some recent work attempts to directly measure these investments. Hulten and Hao (2012) estimate that intangible investment in China was 7.5 percent of GDP in 2006, although they acknowledge that the exercise is "greatly hampered by uncertainty about the accuracy of the data" (p. 6). Furthermore, considerable debate surrounds the source of the intangible investments - that is, whether the government is the source of the spending in order to meet its goals for technological advancement or whether firms are choosing to make the investments themselves (see Hao, 2012). Here, we use a theoretical framework, which is parameterized in such a way as to be consistent with measured statistics in the national and international accounts, to indirectly infer the intangible investment in China and elsewhere. ${ }^{14}$

\section{Evidence for the Mechanisms}

In this section, we present evidence for the key mechanisms we introduce into our model. First, we document the existence of the quid pro quo trade-off that foreign firms face in China, namely, technology capital in exchange for market access. Second, we provide evidence that the rights being traded are for rights inside China, not outside.

\subsection{Quid Pro Quo: Technology Capital Transfer for Market Access}

We start by documenting that access to China's market for multinational firms in high technology industries comes at the price of technology transfer. Prior to China's 2001 accession to the WTO, quid pro quo (henceforth QPQ) was explicit policy. For example, in 1994, China's State

14 In recent work, Ramondo, Rappaport, and Ruhl (2012) study intrafirm trade of U.S. multinationals and provide evidence consistent with the view that a primary motivation for FDI is the transfer of intangible inputs-rather than tangible inputs - across production units. 
Planning Commission introduced a policy initiative that detailed the specific technology transfer requirements for foreign firms that wanted to enter the domestic automobile market. All foreign investment had to be in the form of a joint venture with a domestic partner. The policy initiative contained a technology threshold for the joint venture, requiring it to have "the capacity for manufacturing products which attain the international technological levels of the 1990s." ${ }^{15}$ Furthermore, the policy required that "an office responsible for technological research and development must be set up within the enterprise" (Walsh, 1999, p. 47). Under the terms of accession to the WTO, technology transfer requirements for market access are not permitted, and the Chinese government is generally careful not to make explicit statements about QPQ. ${ }^{16}$ Nevertheless, the widely held view - in government reports and throughout the business community - is that China continues to impose technology transfer requirements as an implicit policy. ${ }^{17}$ Maintenance of this policy is consistent with official Chinese government pronouncements that a key policy goal is indigenous innovation.

Foreign firms are generally reluctant to go on record about technology transfer requirements because of confidentiality issues and fear of retaliation by the Chinese government (see Shea, 2012). Therefore, examining the results of recent confidential surveys is useful. In its 2012 survey of members, the U.S.-China Business Council - a trade group made up of 230 large U.S. firms with significant business interests in China - found that " 85 percent of companies report that they are at least somewhat concerned about transferring technology to China" and "36 percent of respondents indicated they were asked in the past three years to make such a transfer as a requirement for gaining an investment, project, product or market entry approval" (U.S.-China Business Council, 2012a, 2012b). These findings are corroborated in another recent survey by the American Chamber of Commerce in China (AmCham China, 2013). In the survey, 35 percent answered positively to the question "Is de facto technology transfer as a requirement for market access in China a concern for you?" Moreover, a majority of those responding indicated that these requirements were increasing over time rather than decreasing. ${ }^{18}$ These survey findings are inconsistent with the notion that QPQ is a thing of the past now that China is part of the WTO. ${ }^{19}$

Maintaining a QPQ policy is feasible for China because it has mechanisms in place that

15 The policy paper was published under the title "Automotive Industry Industrial Policy" (see Walsh, 1999, Table 17). See also U.S. Congress (1987) for a discussion of earlier Chinese policies on technology transfer.

16 Paragraph 7.3 of the 2001 China accession protocol states, "China shall insure...investment...is not conditioned on...the transfer of technology" (see WTO, 2001).

17 For the U.S. government, see, in particular, United States International Trade Commission (USITC, 2010). For Europe, see the European Commission's (2011) how-to guide for investing in China, which matter-of-factly notes that "over the years, gaining market access in exchange for bringing foreign technology to China has been a successful bargain for many European companies."

18 Excluding nonresponses and "Don't know," 57 percent chose "Increasing," 38 percent chose "Staying the same," and only 5 percent chose "Decreasing."

19 Recent research shows that these forced technology transfer deals actually work as intended, namely, they upgrade the domestic partner. Van Reenen and Yueh (2012), for example, provide evidence that the partner's TFP increases after such deals. 
enforce technology transfer. In particular, China continues to impose joint venture requirements in priority industries. Moreover, joint venture contracts require approval by government officials, and these officials retain significant discretion in approval decisions (see Shea, 2012). The main policy document that regulates entry of foreign firms into China has categories with specific notations about joint ventures, with rules that vary by industry. These rules were introduced in 1995 and have been updated periodically since then. For example, in the 2007 document, under item 19, "manufacturing of complete automobiles," is the stipulation that "foreign investment shall not exceed 50 percent" (see China Ministry of Commerce, 2007).

\subsection{Terms of the Deal: Property Rights Inside China, Not Outside}

In principle, one can imagine a deal in which a foreign multinational obtains access to China's market in exchange for a particular set of technology capital property rights that apply throughout the world. Although China has the ambition to own technology capital with global reach, and although leakage may occur outside of China in FDI technology transfer deals, our hypothesis is that the property rights being exchanged in market access deals are primarily rights inside China, not outside. Here, we present evidence from patent data that is consistent with this hypothesis. We examine initial ownership of new patents by large multinational firms that are doing FDI in China. We show that although these firms may jointly hold patents with domestic partners inside China, shared ownership effectively stops at the border.

Ideally, we would analyze the licensing terms of existing patents, which is the primary channel for technology transfer (see, for example, discussions in U.S.-China Business Council, 2012a, 2012b, and European Commission, 2011). We focus on initial ownership of new patents, because this information is publicly available in the published patent data, whereas licensing terms are generally confidential. The published data are informative because technology transfer deals potentially lead to new patents through two channels. First, Chinese contract law creates certain default rights to firms' licensing technology, specifically the ability to claim property rights for subsequent innovations, and these rights connect technology transfer deals in China with subsequent innovations and patents (see Articles 343 and 354 of China Supreme People's Court, 1999). Because of such laws, the European Union's Small and Medium Enterprises (SME) Centre - a European initiative to help firms do business in China- explicitly recommends that firms "should negotiate a non-exclusive license to improved technology for the Chinese territory and an exclusive license outside of Chinese territory for the usage of the improved technology (see EUSME Centre, 2014). The second channel for new patents is the creation of joint venture $R \& D$ centers, such as those mandated by

the automobile industry regulation discussed earlier, which are likely to result in jointly owned patents. 
To construct our sample of multinationals, we begin with data for foreign affiliate sales, provided by China's Ministry of Commerce, for the top 500 foreign affiliates in 2007 as ranked by domestic sales in China. After consolidating business units of the same firms and excluding firms from Taiwan, we are left with a list of 114 large foreign multinationals with affiliate sales in China of $\$ 314$ billion in 2007..$^{20}$ Joint ventures are significant in the data. In fact, 46 percent of the affiliate sales in the data are in business units where the affiliate name includes a Chinese partner as well as the foreign multinational. Of the 50 largest firms in the data, 86 percent have at least one business unit that is a joint venture. Note that reported sales are for the domestic market, not export processing. ${ }^{21}$

For this sample, we examine data on patent applications in China for the years 2005-2010 and focus on patents that are classified as the invention type. ${ }^{22}$ The data are patent applications that have reached the publication phase. ${ }^{23}$ We examine the text field of the applicant name and determine which patents include the names of the 114 large foreign multinationals. We then classify a patent as "Shared with Chinese partners" if $(i)$ a Chinese firm is also listed as owning the patent or (ii) the business unit listed on the patent is one in which a Chinese firm has an ownership stake, based on a search of company documents and news reports. Otherwise, we classify the patent as "Exclusive." Across the 2005-2010 sample period, 10,184 patents owned by the foreign multinationals are shared with a Chinese partner and 199,410 are exclusive, as reported in the top part of Panel A in Table 1.

The shared patents speak to both the assignment of property rights in China to Chinese firms and to a link with the technology of foreign multinationals. Our interest here is whether the property rights of the Chinese firms in China extend outside of China. Specifically, we ask two questions. First, do the patents themselves link outside of China? We measure this by determining whether the same patent in China has also been filed as either a U.S. patent application or a WIPO application. ${ }^{24}$ Second, in cases in which patents link outside, are the Chinese firms included in the owner list on the outside applications?

Regarding the first question, Table 1 reports that the fraction of shared patents linked outside of China is quite low, only 1.7 percent. As for the second question, we have examined the applicant

20 The sample includes 34 U.S.-based firms with total sales of $\$ 73$ billion. See Holmes, McGrattan, and Prescott (2013) for further details about the construction of the data set.

21 As noted earlier, Chinese regulations separately categorize plants that sell to the domestic market (ordinary trade) from those that sell to export markets (processing trade). Also, FDI by the United States and Europe in China is primarily aimed at the domestic market. Statistics reported in Branstetter and Foley (2010, Table 13.6) indicate that in 2006, 73 percent of U.S. affiliate sales in China were for the local market.

22 Invention patents require a higher inventive threshold than utility patents. We exclude utility patents because they are of negligible importance for foreign firms.

23 Publication of a patent application is an intermediate stage between the application for a patent and the grant of a patent. Some applications are withdrawn before the publication stage.

24 A WIPO application standardizes the process of applying for patent protection in multiple countries. 
name fields of the 177 patents that make up the 1.7 percent with links to U.S. or WIPO applications. Of these, the Chinese firm is listed on the outside application in 21 instances. In summary, for only 21 out of 10,184 shared patents, or 0.2 percent, does Chinese ownership of shared technology with foreign multinationals extend outside the Chinese border.

To put these findings into perspective, a useful approach is to examine the extent to which other Chinese patents link outside. Most foreign-owned patents in China are filed first in foreign countries (typically in the country in which the inventive activity takes place) and afterward brought into China through a filing at the Chinese patent office. Patents that start outside, and then come in, obviously link outside. We can see in Table 1 that 86 percent of the exclusive foreign multinational patents link outside. To make comparisons more direct, we focus on patents in China filed first in China. Virtually all of the shared patents are filed first in China.

We first compare the shared patents with exclusive patents owned by Chinese firms. To construct the latter set, we begin with patents first filed in China and then remove any remaining patents of large multinational firms, as well as patents of academic institutions. ${ }^{25}$ We can see in Table 1 that 4.7 percent of exclusive Chinese firm patents subsequently go outside of China. Note that the set of Chinese firm applicants as a whole includes many small firms. To obtain a group of Chinese applicants that is more comparable in size to our sample of 114 large foreign multinational firms, we select the top 100 Chinese applicants by counts of patents. We find that 16.5 percent of patents of large Chinese patenters subsequently go outside. Note the sharp differences here. If a large Chinese firm has its name on an exclusive patent - that is, one not shared with a foreign multinational - then 16.5 percent of the time it has its name on a corresponding patent outside of China. If ownership is shared, however, the probability drops to 0.2 percent.

Next we look at the patents of our sample of large foreign multinationals that are first filed in China. There are 12,446 of these patents, and 10.1 percent subsequently go outside-about seven times higher than the rate for the shared patents. In addition to conditioning on patents first filed in China, we can further condition on whether the applicant name field specifies a Chinese subsidiary of the multinational and whether the set of inventors includes at least one with a Chinese name. In this way, we focus on technology of the foreign multinational in cases with the inventive activity likely occurring in China. The results are similar. Comparing exclusive and shared patents, the rates of subsequently going outside are 10.6 and 2.0 percent, respectively, so again, we see a sharp difference.

In our earlier discussion we highlighted the automotive industry, and Panel B of Table 1 presents results specifically for this case. Twelve foreign multinationals produce automobiles in China, and all of them do so through joint ventures with one or more of seven major Chinese auto

25 We also manually process large patenters to eliminate patents in which the applicants are individuals rather than firms. 
companies. ${ }^{26}$ Rows 1 and 2 of Panel B correspond to the Chinese patents owned by multinationals that are, respectively, shared and exclusive, with their Chinese partners. As in Panel A, it is evident that shared patents stay inside China, whereas the exclusive patents go outside. The remaining two rows of Panel B correspond to exclusive patents owned by domestic Chinese firms. In row 3 are exclusive patents owned by the seven firms with foreign partners (the joint venture firms); in row 4 are exclusive patents owned by the six main independent automakers. ${ }^{27}$ The Chinese firms with joint ventures have exclusive ownership of very few patents (less than one-third of what the independents own), even though they outproduce the independents by a factor of four. This fact makes clear that the joint-venture Chinese firms obtain their technology mainly from foreign partners.

\section{Theory}

The model is an extension of McGrattan and Prescott $(2009,2010)$ that includes the QPQ mechanism and the choice of an intensity level with which to deploy technology capital in a particular market. We work with an aggregate production function, derived by aggregating first across plants and then across companies. The aggregate technologies are embedded in a multicountry general equilibrium model with two types of firms: multinationals that have technology capital that is nontransferred and appropriators that have technology capital that has been transferred to them through QPQ arrangements.

\subsection{Multinational Problem}

Consider the problem of a multinational with nontransferred technology capital that chooses the scale of overseas operations to maximize the present value of after-tax worldwide dividends,

$$
\max \sum_{t} p_{t}\left(1-\tau_{d t}\right) D_{t}^{j}
$$

where $t$ indexes time, $j$ indexes the country where the multinational is incorporated, $p_{t}$ is the Arrow-Debreu price, $\tau_{d}$ is the tax rate on shareholder dividends, and $D^{j}$ is the aggregate dividend payment.

The aggregate dividend payment for multinational firm $j$ is the sum of dividends across FDI

26 The twelve foreign companies are Toyota, Honda, Nissan, Hyundai, Ford, Volkswagen, General Motors, Mazda, Daimler, Suzuki, Peugeot Citroen, and BMW. The seven Chinese automakers that operate through joint venture are SAIC, Dongfeng, FAW, Changan, BAIC, GAC, and Brilliance. The separate appendix in Holmes, McGrattan, and Prescott (2014) provides further details.

27 These are Great Wall, Chery, Geely, JAC, BYD, and Lifan. We restrict attention to those automakers that produced 200,000 or more units in 2012. See Holmes, McGrattan, and Prescott (2013) for further details. 
host countries $i=1, \ldots, I$,

$$
D_{t}^{j}=\sum_{i}\left\{\left(1-\tau_{p, i t}\right)\left(Y_{i t}^{j}-W_{i t} L_{i t}^{j}-\delta_{T} K_{T, i t}^{j}-X_{I, i t}^{j}-\chi_{i}^{j} X_{M, t}^{j}\right)-K_{T, i, t+1}^{j}+K_{T, i t}^{j}\right\}
$$

with $\chi_{j}^{j}=1$ and $\chi_{i}^{j}=0$ if $i \neq j$. The dividend from country $i$ is computed as the after-tax accounting profit less retained earnings. The tax rate in country $i$ is given by $\tau_{p, i}$. This tax is assessed on the taxable profit, which is equal to output $Y_{i}^{j}$ less payments to labor $L_{i}^{j}$ at rate $W_{i}$, depreciation of tangible capital $K_{T, i}^{j}$ at rate $\delta_{T}$, new investment in intangible capital $X_{I, i}^{j}$ that is specific to a location (that is, a plant in country $i$ ), and investment at home in new technology capital $X_{M}^{j}$ that, when accumulated, is intangible capital that can be used simultaneously in multiple locations across the globe. When computing profits, investments in tangible capital are treated as capital expenditures, implying that the firm subtracts only the depreciation allowance, whereas investments in the two intangible capitals are treated as expenses and therefore fully subtracted. This differential treatment, in turn, implies that retained earnings recorded by the accountants are net investment in tangible capital, which is given by $K_{T, i, t+1}^{j}-K_{T, i t}^{j}$ between period $t$ and $t+1$.

In each period $t$, total output produced by multinationals from $j$ in host country $i$ is given by

$$
\begin{aligned}
& Y_{i t}^{j}=A_{i t} \sigma_{i t}^{j}\left(q_{i t}^{j} M_{i t}^{j} N_{i t}\right)^{\phi}\left(Z_{i t}^{j}\right)^{1-\phi} \\
& Z_{i t}^{j}=\left(K_{T, i t}^{j}\right)^{\alpha_{T}}\left(K_{I, i t}^{j}\right)^{\alpha_{I}}\left(L_{i t}^{j}\right)^{1-\alpha_{T}-\alpha_{I}},
\end{aligned}
$$

which is the production function derived by aggregating across plants and across companies. This aggregate production function depends on the host country's TFP denoted by $A_{i t}$ and its degree of openness to FDI denoted by $\sigma_{i t}^{j}$, which is equal to 1 if $j=i$ and $\sigma_{i t} \in[0,1)$ if $j \neq i$. We view the TFP and openness parameters as government policies taken as given by multinationals when deciding how much FDI to do in country $i$. Given these policies, multinationals in $j$ choose how much of their available technology capital, denoted by $M_{i}^{j}$, to deploy in country $i$. This is the nontransferred stock of capital.

The stock of technology capital $M_{i}^{j}$ can be used nonrivalrously, but it is indexed by the FDI host country $i$, since FDI host countries differ in their QPQ policies; companies may have less available technology capital to use in countries that require QPQ than in countries that do not if technology transfers have already taken place. Furthermore, because of QPQ requirements, we assume that countries may choose to deploy less technology capital than is available. At the aggregate level, the fraction of technology capital deployed in country $i$ by companies in $j$ is denoted $q_{i}^{j}$ - which we refer to as the intensity level - and the total effective stock of technology capital is therefore $q_{i}^{j} M_{i}^{j}$, with $q_{i}^{j} \in[0,1]$ and $q_{i}^{i}=1$. 
Country $i$ has a total of $N_{i}$ locations in which to operate, and like TFP and FDI openness, we treat this as a characteristic of the country that is taken as given by multinationals. McGrattan and Prescott $(2009,2010)$ use the concept of locations to account for differences in scale across countries, and we follow that convention here by assuming in the quantitative analysis that a country's count of locations is proportional to its population size. The number of locations is important for the concept of equilibrium used here, since technology capital is nonrivalrous and is used simultaneously at multiple locations (or equivalently for multiple people). The rivalrous factors of production appear in the composite input $Z_{i}^{j}$, namely, tangible capital $K_{T, i}^{j}$, intangible capital that is location specific $K_{I, i}^{j}$, and the labor input $L_{i}^{j}$. If there are decreasing returns to the rival factors at the plant level, then companies choose to split these factors evenly across available locations $N_{i}$.

The first innovation of our model, relative to McGrattan and Prescott (2009, 2010), is to introduce the intensity choice $q_{i}^{j}$ described above, for the level at which technology capital is deployed, location by location. To get back to McGrattan and Prescott, we can just assume that intensity choices are fixed at the upper bound of one, that is, $q_{i}^{j}=1$ for all $i, j$.

The second innovation of our model is to incorporate QPQ policy. When a multinational from $j$ chooses to deploy technology capital in $i$ at time $t$ at intensity $q_{i t}^{j}$, a share $h_{i t}^{j}\left(q_{i t}^{j}\right) \in[0,1]$ of the technology capital must be transferred to a local firm (the appropriator). Next period technology capital is given by

$$
M_{i, t+1}^{j}=\left(1-\delta_{M}\right)\left(1-h_{i t}^{j}\left(q_{i t}^{j}\right)\right) M_{i t}^{j}+X_{M, t}^{j},
$$

where the first term on the right-hand side is undepreciated capital less technology transfers and the second term is the new technology capital. Notice that the property rights being transferred are specific to the destination country $i$, an assumption that we motivated earlier with the patent data. ${ }^{28}$ We assume that the function $h_{i t}^{j}(\cdot)$ is weakly increasing in the intensity choice $q_{i t}^{j}$ and is weakly convex. The fact that it is upward sloping captures the terms of the quid pro quo - the more technology capital brought in, the greater the required transfer. The convexity assumption captures the idea that a firm might be able to get away with transferring small (perhaps less important) ideas when the request for market access is low, protecting the most advanced and important ideas (sometimes called the "crown jewels") by keeping them at home. Large market access, however, might come only at the price of the crown jewels. ${ }^{29}$

In terms of the interpretation of the function $h_{i}^{j}(q)$, we think of it as broadly capturing the kinds of policies discussed in Section 3, such as forced joint ventures. The special case of $h(q)=q$

28 If $h_{i t}^{j}\left(q_{i t}^{j}\right)$ is equal to zero for all $i, j$, and $t$, then $M_{i t}^{j}=M_{t}^{j}$ does not depend on the host country as in the McGrattan-Prescott model.

29 An alternative structure that would produce similar results would have a proportional QPQ tax and curvature in the decision problem through a location-level setup cost that is convex in the intensity choice. 
has a particularly simple interpretation, namely that any capital deployed in the current period is transferred to domestic firms for future periods. As an example, the German company Siemens had a joint venture with China National Rail (CNR) that completed China's first high-speed rail line in 2008. The next line was built by CNR, with only a minor role for Siemens (see USITC, 2010, pp. 4-11).

Two additional capital accumulation equations are needed to complete the description of the multinational's problem, namely,

$$
\begin{aligned}
K_{T, i, t+1}^{j} & =\left(1-\delta_{T}\right) K_{T, i t}^{j}+X_{T, i t}^{j} \\
K_{I, i, t+1}^{j} & =\left(1-\delta_{I}\right) K_{I, i t}^{j}+X_{I, i t}^{j},
\end{aligned}
$$

where $K_{T, i}^{j}$ and $K_{I, i}^{j}$ are stocks of tangible and intangible capital, respectively, used by multinationals from country $j$ that are aggregates of capital allocated to specific locations in country $i$. New investments are given by $X_{T, i}^{j}$ and $X_{I, i}^{j}$, and the stocks depreciate at rates $\delta_{T}$ and $\delta_{I}$, respectively, for tangible and intangible capital. Note that QPQ transfers only show up in the accumulation equation for technology capital, thereby implying an asymmetry between the location-specific capital stocks and the nonrivalrous technology capital. ${ }^{30}$

There are several noteworthy aspects of the multinational's problem. First, given the nonrivalrous nature of technology capital, multinationals will want to employ it in foreign countries, even in the face of QPQ. ${ }^{31}$ This is true even in the special case of $h(q)=q$. The host government appropriates, beginning tomorrow, everything coming in today. On the balanced growth path of such an economy, optimal policy is to set $q=1$, since 100 percent of the effective technology capital is appropriated. It makes sense to bring everything in as soon as possible and collect profits today, rather than wait and incur depreciation and discounting. If instead, the QPQ function $h(q)$ is strictly convex, there is an incentive to smooth the deployment of an idea, and the optimal intensity may be interior, $q<1$. Furthermore, if the host country is growing rapidly, a firm may set $q<1$, to hold out for bigger returns on technology capital in future periods. Both of these factors play a role in our quantitative analysis.

Another noteworthy aspect of the multinational's problem is that policies of large host countries can have nonnegligible effects on the investment decisions of multinationals. More precisely,

30 For some parameterizations of our model, nonnegativity constraints bind for investments, especially initial investment of technology capital of countries that obtain capital through QPQ. To prevent nonnegative investments, we include a small subsidy for investment in technology capital when levels fall close to zero. We also include adjustment costs to avoid large initial changes in investment along the transition path. The subsidy and adjustment costs are chosen to be as small as possible to avoid violating the constraints. See Holmes, McGrattan, and Prescott (2014) for details.

31 Production is Cobb-Douglas in nonrivalrous technology capital and rivalrous inputs. Therefore, the use of an idea in a foreign country will always require local inputs. Nevertheless, because of the standard Inada condition, it will always be optimal to bring in technology capital, regardless of the costs of rivalrous complementary inputs. 
if a host country $i$ is small (where $N_{i t}$ goes to zero relative to $\sum_{i^{\prime}} N_{i^{\prime} t}$ ), then the particular QPQ parameters for host $i$ will be irrelevant in technology capital investment decisions for multinational firms. If, on the other hand, $N_{i t}$ makes up a non-negligible share of the world economy, its QPQ policies feed back into the investment decisions of potential FDI investors. We will see this force at work in our quantitative analysis.

\subsection{Appropriator's Problem}

Appropriators also maximize the present after-tax discounted stream of dividends. Dividends accruing to the transferred technology capital are given by

$$
\tilde{D}_{i t}=\left(1-\tau_{p, i t}\right)\left(\tilde{Y}_{i t}-W_{i t} \tilde{L}_{i t}-\delta_{T} \tilde{K}_{T, i t}-\tilde{X}_{I, i t}\right)-\tilde{K}_{T, i, t+1}+\tilde{K}_{T, i t} .
$$

and are distributed to households in country $i$. Note that tildes are used to distinguish choices of the appropriators in $i$ from choices of the multinationals $j$ operating in $i$. The relevant inputs for the appropriators are the profits tax rate $\tau_{p, i}$, output $\tilde{Y}_{i}$, payments to labor $\tilde{L}_{i}$ at wage rate $W_{i}$, depreciation of tangible capital $\tilde{K}_{T, i}$ at rate $\delta_{T}$, and new investment in plant-specific intangible capital $\tilde{X}_{I, i}$. The production technology in this case is

$$
\begin{aligned}
& \tilde{Y}_{i t}=A_{i t} \zeta\left(\tilde{M}_{i t} N_{i t}\right)^{\phi}\left(\tilde{Z}_{i t}\right)^{1-\phi} \\
& \tilde{Z}_{i t}=\left(\tilde{K}_{T, i t}\right)^{\alpha_{T}}\left(\tilde{K}_{I, i t}\right)^{\alpha_{I}}\left(\tilde{L}_{i t}\right)^{1-\alpha_{T}-\alpha_{I}},
\end{aligned}
$$

and the evolution of the capital stocks is given by

$$
\begin{aligned}
\tilde{M}_{i, t+1} & =\left(1-\delta_{M}\right) \tilde{M}_{i t}+\sum_{j}\left(1-\delta_{M}\right) h_{i t}^{j}\left(q_{i t}^{j}\right) M_{i t}^{j} \\
\tilde{K}_{T, i, t+1} & =\left(1-\delta_{T}\right) \tilde{K}_{T, i, t+1}+\tilde{X}_{T, i, t+1} \\
\tilde{K}_{I, i, t+1} & =\left(1-\delta_{I}\right) \tilde{K}_{I, i, t+1}+\tilde{X}_{I, i, t+1},
\end{aligned}
$$

where $\zeta$ is the transfer TFP discount, $\tilde{M}_{i}$ is transferred technology capital, and $\tilde{K}_{T, i}$ and $\tilde{K}_{I, i}$ are rival tangible and intangible capital, respectively. Notice that appropriators do not make new investments but rather are the recipients of technology capital from foreign multinationals (see equation (4.4)).

Our general structure allows the production specification for appropriators to differ from multinationals because of two factors that work in opposite directions. First, notice that in the multinational production function (4.2), there are the parameters governing the degree of openness, $\sigma_{i t}^{j}$, and the intensity level of multinationals, $q_{i t}^{j}$, whereas in the appropriator production function (4.6), these parameters drop out, since both are at the upper bound equal to one. This aspect of the formulation captures the advantage the appropriator has over a foreign firm in being immune 
to obstacles that confront foreign firms. ${ }^{32}$ The appropriator need not worry about QPQ (and can then set intensity to the upper bound of one). Also, it need not worry about general barriers to foreigners, as captured in $\sigma_{i t}^{j}$. Second, we introduce a transfer TFP discount term $\zeta \leq 1$ to allow for the possibility that appropriators are less productive than the foreign multinational who developed the technology being transferred. In the baseline quantitative model, we simplify by focusing on the limiting case where $\zeta=1$, but then in Section 7 we consider $\zeta<1$.

Although we have emphasized the quid pro quo nature of transfers, it is worth noting that our general formulation includes outright expropriation as a special case. In particular, suppose the QPQ function satisfies $h_{i t}^{j}\left(q_{i t}^{j}\right)=\bar{h}_{i t}^{j}$, which is invariant to a firm's choice of intensity $q_{i t}^{j}$. This instance can be interpreted as a case of "quid" without the "quo," where a government expropriates technology capital at a fixed level even if multinationals from $i$ stay completely outside of $j$ (that is, even if $\left.q_{i t}^{j}=0\right){ }^{33}$ Faced with a constant quid pro quo function, it is immediate that foreign firms will raise intensity to the maximum level, $q=1$. In our quantitative model below, the quid pro quo function is strictly upward sloping for a range of $q$, and we get an interior solution, $q<1$, for the advanced countries that brings technology to China. In other words, the advanced countries endogenously hold back, and the key fact in the data that drives this result is the differential FDI behavior between the advanced countries and the rest of the world. We note that if we were to generalize the parameterization of the model to allow the openness parameter for a destination country to vary across source countries, it is possible to fit the same set of facts with a perfectly flat QPQ function. Formally, let $\hat{q}_{i t}^{j}$ be the equilibrium intensity level in our baseline model. Recall that $\sigma_{i t}$ is the openness parameter, which we have assumed to be specific to the destination $i$ but invariant to the source $j$. Call this the baseline model. Now consider an alternative parameterization $\hat{\sigma}_{i t}^{j}=\sigma_{i t}\left(\hat{q}_{i t}^{j}\right)^{\phi}$, with source-specific openness and assume a flat alternative QPQ function $\hat{h}_{i t}^{j}\left(\hat{q}_{i t}^{j}\right)=\bar{h}_{i t}^{j}$. This alternative yields the same outcomes as our baseline model, with the differential FDI behavior now accounted for by exogenous differences in openness across sources instead of differences in endogenous choices of $q$, as in the baseline. Although the baseline model and the alternative fit the same facts, we will see in Section 7 that they differ in their policy implications.

\subsection{Household Problem}

Households choose sequences of consumption $C_{i t}$, labor $L_{i t}$, and assets $B_{i t+1}$ to solve the following

32 Later, we discuss a reinterpretation of $\sigma_{i t}^{j}$ as representing not only barriers determined by policies of the FDI host, but also barriers beyond the control of governments, such as language differences and geographic distance. The latter barriers would continue to exist even after the transfer has occurred.

33 Note, however, that it might be difficult for a country to absorb foreign technology without the cooperation of foreign firms. That is, outright expropriation may be infeasible. Instead, we might see negotiated arrangements, in which foreign firms agree to transfer technology in return for a reward such as market access. 
problem:

$$
\max \sum_{t} \beta^{t}\left[\log \left(C_{i t} / N_{i t}\right)+\psi \log \left(1-L_{i t} / N_{i t}\right)\right] N_{i t}
$$

subject to

$$
\sum_{t} p_{t}\left[C_{i t}+B_{i, t+1}-B_{i t}\right] \leq \sum_{t} p_{t}\left[\left(1-\tau_{l, i t}\right) W_{i t} L_{i t}+\left(1-\tau_{d t}\right)\left(D_{t}^{i}+\tilde{D}_{i t}\right)+r_{b t} B_{i t}+\kappa_{i t}\right],
$$

where $\tau_{l i}$ and $\tau_{d}$ are tax rates on labor and company distributions, $r_{b}$ is the after-tax return on international borrowing and lending, $N_{i t}$ is the population in country $i$ (equivalent to the count of locations as discussed earlier), and $\kappa_{i t}$ is exogenously determined income, which includes both government transfers and nonbusiness net income. ${ }^{34}$ We include nonbusiness net income because we want to match accounts of the model to accounts in the data and, therefore, want to distinguish value added and investment from business and nonbusiness sectors. We also include nonbusiness labor as part of the total labor input, and this too is exogenously set. Public consumption is included with $C_{i}$.

\subsection{Market Clearing}

The worldwide resource constraint is

$$
\begin{aligned}
\sum_{i}\left\{C_{i t}\right. & \left.+\sum_{j}\left(X_{T, i t}^{j}+X_{I, i t}^{j}\right)+X_{M, t}^{i}+\tilde{X}_{T, i t}+\tilde{X}_{I, i t}+\bar{X}_{n b, i t}\right\} \\
= & \sum_{i, j} Y_{i t}^{j}+\sum_{i}\left(\tilde{Y}_{i t}+\bar{Y}_{n b, i t}\right)
\end{aligned}
$$

which is the market-clearing condition for the goods market that includes nonbusiness output $\bar{Y}_{n b, i t}$ and nonbusiness investment $\bar{X}_{n b, i t}$. Recall that these are components of nonbusiness net income for households, which is included in $\kappa_{i t}$ in (4.9).

Market clearing in asset markets occurs if $\sum_{i} B_{i t}=0$, and market clearing in labor markets occurs if

$$
L_{i t}=\sum_{j} L_{i t}^{j}+\tilde{L}_{i t}+\bar{L}_{n b, i t}, \quad i=1, \ldots, I
$$

where $L_{i t}^{j}$ is the labor input for multinationals from $j$ operating in country $i, \tilde{L}_{i t}$ is the labor input of appropriators in country $i$, and $\bar{L}_{n b, i t}$ is the time devoted to nonbusiness work.

Note that because there is only a single consumption good, there is no two-way trade in goods with a period between countries. In general, however, there exists intertemporal trade in goods across countries.

\footnotetext{
34 In our later application, we assume that some countries face borrowing constraints and impose these constraints when computing equilibria.
} 


\subsection{Accounting Measures}

To compare our theory with national and international data, we first need to construct the same accounting statistics for our model that are produced for the national accounts and the balance of payments. In particular, for our quantitative analysis, we need GDP, inward FDI, and outward FDI.

GDP may be computed in two ways: by summing products or by summing incomes. For country $i$, summing products yields

$$
\mathrm{GDP}_{i t}=C_{i t}+\sum_{j} X_{T, i t}^{j}+\tilde{X}_{T, i t}+\bar{X}_{n b, i t}+N X_{i t}
$$

where $N X_{i t}$ is net exports of goods and services by country $i$. Notice that intangible investments are not included here because they are expensed and thus not part of value added. ${ }^{35}$

If GDP is found by summing incomes, we add together wages $W_{i} L_{i}$, total before-tax profits of multinationals with nontransferred capital operating in the country $\sum_{j}\left(Y_{i}^{j}-W_{i} L_{i}^{j}-\delta_{T} K_{T, i}^{j}-\right.$ $\left.X_{I, i}^{j}\right)-X_{M}^{i}$, total before-tax profits of appropriators $\tilde{Y}_{i}-W_{i} \tilde{L}_{i}-\delta_{T} \tilde{K}_{T, i}-\tilde{X}_{I, i}$, tangible depreciation of all businesses $\sum_{j} \delta_{T} K_{T, i}^{j}+\delta_{T} \tilde{K}_{T, i}$, and capital income less investment for the nonbusiness sector, $\bar{Y}_{n b, i}-W_{i} \bar{L}_{n b, i}-\bar{X}_{n b, i}$ :

$$
\mathrm{GDP}_{i t}=\sum_{j} Y_{i t}^{j}+\tilde{Y}_{i t}+\bar{Y}_{n b, i t}-\sum_{j} X_{I, i t}^{j}-X_{M, t}^{i}-\tilde{X}_{I, i t}
$$

In equilibrium, it must be the case that the right-hand side of (4.11) equals the right-hand side of (4.12). Equating the two and summing across countries yields the worldwide resource constraint in $(4.10)$.

Inward and outward FDI are items in the financial accounts of the balance of payments. For the model, the financial account for country $i$ is

$$
\mathrm{FA}_{i t}=\sum_{l \neq i}\left(K_{T, l, t+1}^{i}-K_{T, l t}^{i}\right)-\sum_{l \neq i}\left(K_{T, i, t+1}^{l}-K_{T, i t}^{l}\right)+B_{i t+1}-B_{i t},
$$

where the first term is FDI by multinationals from $i$ operating abroad (outward FDI), the second term is the negative of new investment by foreigners operating in $i$ (inward FDI), and the third term is new portfolio acquisitions by households from $i$. For the accounts to balance, the financial account has to equal the current account, which is the sum of net exports and net factor payments (receipts less payments). Net factor payments are the sum of dividends, retained earnings, and interest income from abroad net of similar payments to other countries.

35 The data we use do not include intellectual property products recently introduced in some national accounts. 


\section{A Multicountry Application}

Next, we describe our strategy for parameterizing the model. We also investigate the model's fit and its implications for the global distribution of technology capital.

\subsection{Model Parameters}

The country groupings used here are a combined entity we call China (which includes mainland China, Hong Kong, Taiwan, and Macao), the United States, Western Europe, Japan, a combined entity consisting of Brazil, Russia, and India (BRI), and a combined entity of non-Caribbean countries not elsewhere listed that had foreign direct investments in China in excess of 0.1 billion U.S. dollars in 2007, which we refer to as rest of world (ROW). ${ }^{36}$ To avoid double counting, we net out intraregional flows when constructing the bilateral FDI statistics for China, Western Europe, BRI, and ROW. The sample period for our analysis is 1990 to 2010. We choose 1990 as our starting point because it is before the significant rise in Chinese inward FDI.

We assume that countries differ in their QPQ policy $\left(h_{i t}^{j}(q)\right)$, level of TFP $\left(A_{i t}\right)$, degree of FDI openness $\left(\sigma_{i t}\right)$, population size $\left(N_{i t}\right)$, and tax policy related to business profits $\left(\tau_{p i}\right) .{ }^{37}$ In all other respects, they are assumed to be the same and, therefore, we use common parameters for household preferences $(\beta, \psi)$, trend growth in TFP $\left(1+\gamma_{A}\right)^{t}$, trend growth in population $\left(1+\gamma_{N}\right)^{t}$, income shares $\left(\phi, \alpha_{T}, \alpha_{I}\right)$, nonbusiness activities $\left(\bar{L}_{n b}, \bar{X}_{n b} /\right.$ GDP, $\bar{Y}_{n b} /$ GDP $)$, depreciation rates $\left(\delta_{M}, \delta_{T}\right.$, $\left.\delta_{I}\right)$, and tax rates on individual incomes $\left(\tau_{l}, \tau_{d}\right)$. Specifically, we use estimates from McGrattan and Prescott's (2010) study of the U.S. current account, which are reported in Table 2, and show separately in Holmes, McGrattan, and Prescott (2014) that our main results are not sensitive to these choices. Finally, for the baseline, we set the transfer TFP discount to $\zeta=1$.

Our model takes population and business tax rates as exogenous. Country populations are reported in Table 3 for selected years (see Appendix A for data sources). ${ }^{38}$ We have data on business tax levels, and for our baseline parameterization we hold the rates fixed at their 1990

36 Western Europe includes Austria, Belgium-Luxembourg, Denmark, Finland, France, Germany, Greece, Ireland, Italy, Netherlands, Norway, Portugal, Spain, Sweden, Switzerland, and United Kingdom. Rest of world includes Australia, Bahrain, Canada, Indonesia, Korea, Malaysia, Mauritius, Philippines, Samoa, Saudi Arabia, Singapore, and Thailand. We include BRI as a comparison with China and its provinces because they share many similarities at the start of our sample. In our baseline model, we exclude inward FDI from Caribbean countries because these flows are primarily related to sheltering taxes. In our sensitivity analysis, we change regional assignments by adding net inflows from the Caribbean islands and including Korea with Japan rather than with ROW.

37 We also assume differences in policies related to portfolio flow restrictions because some of the countries in our sample still have tight capital controls on portfolio investments. Specifically, for the baseline parameterization, we assume that portfolio flows are completely free in the United States, Western Europe, and Japan and completely restricted elsewhere. As a check on this assumption, we consider an alternative version of the model with free portfolio flows across all countries. See Prasad and Wei (2007) for a nice survey of capital controls in China and Holmes, McGrattan, and Prescott (2014) for details on the alternative model.

38 The time period of the model is annual, but we choose the parameters to fit trends in the data and, thus, only report selected years in the input tables. Inputs for all years are reported in Holmes, McGrattan, and Prescott (2014). 
levels, which, in percentage terms, equal 32.9, 38.6, 42.9, 50, 35, and 32.1 for China, the United States, Western Europe, Japan, BRI, and ROW, respectively. ${ }^{39}$

In our model, GDP and FDI flows are endogenous. We choose values for country TFPs, degrees of openness, and QPQ, such that the equilibrium GDP levels and FDI flows in the model match their counterparts in the data. ${ }^{40}$ Our prior is that use of QPQ by the advanced countriesthe United States, Western Europe, Japan - is negligible, so we assume $h_{i t}^{j}(q)=0$, for $i$ equal to the index for these host countries, for all sources $j$. We assume China imposes QPQ on inward FDI from the advanced countries but does not impose it on the rest of world countries. Ample evidence indicates that the United States, Europe, and Japan are very different from the rest of the world with respect to the high-tech nature of their research and patent activity. ${ }^{41}$ The advanced countries have the frontier knowledge that China particularly desires to obtain, including technologies that have military applications. ${ }^{42}$ The technology capital of the rest of the world, including brands of restaurants and banks, tends to be relatively less technologically advanced. This motivates our assumption that China's QPQ policy concentrates on the advanced countries. Specifically, we parameterize China's QPQ policy to the advanced countries so that the share of inward FDI coming from the advanced countries to China and its provinces has the same trend in the model and the data.

We have no bilateral FDI flows for the BRI countries. We need to make some assumptions about BRI's policy and for simplicity we treat BRI as having the same QPQ policy as China. Furthermore, we assume that BRI imposes QPQ on China and vice versa. We experiment with alternative assumptions, such as the assumption that BRI does not impose QPQ. Our results, including the welfare effects of China's QPQ, are robust to these alternative assumptions. We discuss these results further in Sections 6 and 7. Finally, we assume that the rest of world countries do not impose QPQ.

The functional form for QPQ for hosts $i$ that impose QPQ is given by

$$
h_{i t}^{j}(q)=\min \left\{\bar{h}_{t} q \exp (-\eta(1-q)), 1\right\}
$$

39 In our sensitivity analysis, we feed in time-varying rates for China and find that our results are robust to this extension.

40 We do not model domestic policies that led to improvements in the technology parameters $A_{i t}$ - which may include policies related to greater openness - but rather we treat these policies as exogenous. See Hsieh and Klenow (2009) and Song, Storesletten, and Zilibotti (2011), who investigate policies that affect growth in China's productivity.

41 The National Science Foundation (NSF, 2012) reports that the value-added share of U.S. industries categorized as knowledge-intensive services or high-technology manufacturing is 36.3 percent of GDP in 2000, which is the midpoint of our sample period. For the same year, the Organisation for Economic Co-operation and Development (OECD) reports the annual number of grants for triadic patents - patents granted by each of the patent offices in the United States, the European Union, and Japan-to be 49.1, 36.3, and 117.0 per million in the population for the United States, Western Europe, and Japan, respectively, compared with only 3.5 for ROW and 0.1 for both China and BRI.

42 The strategic plan laid out in China State Council (2006) for indigenous innovation is clearly aimed at high-tech capital rather than low-tech. 
which is weakly increasing in $q$. The choice of this functional form is motivated by the fact that we need some curvature in the function (that is, $\eta>0$ ) in order for an interior equilibrium to exist. In our baseline model, we set $\eta=10$ and check to make sure that the results are robust to a range of values for $\eta{ }^{43}$ We leave the path of $\bar{h}_{t}$ as a sequence of free parameters and interpret the changes in these parameters over time as changes in policy. A higher value of $\bar{h}_{t}$ is associated with higher QPQ transfer rates. ${ }^{44}$

Smooth sequences for $\left\{A_{i t}, \sigma_{i t}, \bar{h}_{t}\right\}, i=1, \ldots, 6$, are chosen to fit trends in real per capita GDP for the six economies, inward FDI to the six economies, and the share of FDI coming to China from the advanced countries. That is, we set paths for the thirteen parameter sequences so that the model generates the same trends as our thirteen observed series. In Tables 4 and 5 , we report the inputs for TFPs, openness, and QPQ costs needed to match these trends in the data. Parameters in the top panel of Table 4 are the total factor productivities $\left(A_{i t}\right)$. Trends in real GDP are especially sensitive to changes in TFP choices. Notice that matching observations requires a large increase in China's TFP. For Western Europe and BRI, there was little catch-up to U.S. levels, and thus we have nearly constant TFP paths. Japan actually experienced a decline in relative TFPs. The bottom panel of Table 4 shows the degree of openness parameters $\left(\sigma_{i t}\right)$. Trends in observed inward FDI are especially sensitive to changes in the inputs for the degree of openness. Japan stays relatively closed to FDI throughout the period. China and BRI, on the other hand, become much more open.

In Table 5 we report the equilibrium values of the transfer rates, that is, $h_{i t}^{j}(q)$, that result from the QPQ policy. (We report these values because their economic magnitudes are more readily interpretable than the values of the $\bar{h}_{t}$ parameters.) To match the bilateral flows, the QPQ transfer rates faced in China by multinationals from the advanced countries must have grown. For example, in 1990, multinationals are transferring technology capital to China at a rate of 0.2 percent per year. This rate rises to 4.4 percent per year by 2010. We have not modeled the choice of policy by the Chinese government, but it is intuitive that the vast expansion of the Chinese market gives it more bargaining power.

\subsection{Model Fit}

In Figures 3-5, we display the implied model outputs along with their empirical analogues. We make several adjustments to GDP and FDI data to facilitate comparisons between the model and

43 What matters are the paths of the equilibrium intensity levels and QPQ costs, which in turn determine the share of FDI coming to China from advanced countries. To match this share, we need to vary the path of $\bar{h}_{t}$ as we vary the elasticity $\eta$.

44 Section 7 considers variations in the baseline model including one with fixed QPQ policy. In this case, with $\bar{h}_{t}$ constant, the model cannot generate the full drop in the share shown in Figure 5 , but the main results are not significantly different from the baseline, because China's large rise in TFP plays a central role for the equilibrium choice of intensity level. 
the data. First, we divide the per capita GDPs for all countries by U.S. per capita GDP; this step allows us to normalize $A_{1 t}$ to 100 for all $t$ without loss of generality. The results for real per capita GDP are shown in Figure 3. Second, we cumulate the inward FDI over time because there are large fluctuations in the year-by-year investments. We then deflate these investments, which are in nominal terms, and detrend them by dividing by population and the common world growth trend in technology. In order to facilitate comparison, we divide the series for cumulated FDI relative to trend by the value for China in 2010 (which is shown in Figure 1). Inward FDI flows for the model and data are shown in Figure 4. The parameters of the baseline model are chosen with the goal of fitting these targets, and the resulting fit is very good.

The final target to consider is the share of inward FDI coming from the advanced countries to China. Figure 5 shows the fit of the baseline model to this target. The data series in Figure 5 is derived by taking the ratio of inward FDI from advanced nations in Figure 1 and dividing by the total inward FDI. The same time series is constructed for the model economy. Again, the model economy fits the target well.

In our procedure, we did not target China's outward FDI flows. We next examine how the baseline model fits this additional aspect of the data, which provides an external check of the framework. Specifically, we construct cumulated outward flows in an analogous way to the inward FDI series shown in Figure 5: we take the ratio of cumulated FDI from China - in particular, the cumulation of flows shown in Figure 2 - relative to trend GDP, where trend GDP is China's GDP in 1990 times the common growth trend. The series for the model and data are normalized by China's cumulative inward FDI relative to trend GDP in 2010 (as we did in Figure 5). The results are displayed in Figure 6. The baseline model fits this nontargeted aspect of the data relatively well. In the data, China's cumulated outward FDI by 2010 is roughly 40 percent of China's cumulated inward FDI. The baseline model predicts this statistic to be around 50 percent, only slightly higher than the actual level.

For the sake of comparison, we have also considered fitting a restricted model in which QPQ policy by China (and BRI) is set to zero. For this limiting case, the model reduces to that in McGrattan and Prescott $(2009,2010) .{ }^{45}$ Figure 6 shows the predicted FDI outflows from China for this restricted model, in addition to the baseline. Unlike the baseline model, the restricted model with no QPQ fits the data poorly, overpredicting actual outflows by a factor of five. ${ }^{46}$ Without QPQ transfers, Chinese firms must develop their own technologies, but if they do, they can take these technologies abroad, and that is why predicted outflows of this model are so large.

45 TFP and openness parameters are chosen so as to match Figures 3 and 4. See Holmes, McGrattan, and Prescott (2014) for details of the model inputs for the restricted model without QPQ.

46 Both versions of the model predict that bilateral outward flows from China are roughly proportional to GDPs in recipient countries, which leads to an overprediction of the fraction of China's outflows that go to technologically advanced countries. Adding a preferential bias for goods from countries in similar income groups as in Fajgelbaum, Grossman, and Helpman (2014) would help along this dimension. 
With QPQ, Chinese firms tend to obtain technology in the form of transfers, which by contract they are unable to take outside of China.

In Holmes, McGrattan, and Prescott (2014), we demonstrate that the results in Figure 6 for the restricted model without $\mathrm{QPQ}$ are little changed even if we allow for a more flexible specification of FDI openness in which $\sigma_{i t}^{j}$ is indexed by the source and destination pair $(i, j)$. This generalization allows for a broader interpretation of the costs of FDI, which may be significant when host countries are distant or have languages different from the source country. These country-pair specific discounts are often highlighted in the literature (see, for example, Keller and Yeaple, 2013, and Ramondo and Rodríguez-Clare, 2013). If we have complete freedom to set the paths $\sigma_{i t}^{j}$ for all $i, j$, and $t$ in arbitrary ways, we can fit any bilateral capital flows. Instead, we assume that there exists a discount $\xi<1$ on the ability to transfer technology capital between one group of countries that are close in terms of geography or language and the remaining countries. Specifically, we replace $\sigma_{i t}$ with $\tilde{\sigma}_{i t}^{j}=\xi \sigma_{i t}$ if $i$ and $j$ are not close and $\tilde{\sigma}_{i t}^{j}=\sigma_{i t}$ if $i$ and $j$ are close. Leaving $\xi$ constant over time is appropriate to the extent that it is based on distance and language differences that are constant over time. In setting $\sigma_{i t}^{j}$, we assume that the United States and Western Europe are close and that the remaining - mostly Asian - countries are close. We also vary $\xi$ and recalibrate the parameters discussed in Section 5.1 in order to match Figures 3 and 4 as before. We show that allowing for $\xi<1$ in the model without QPQ makes no headway in fitting the pattern of the declining share of FDI from the technologically advanced countries into China and little headway in accounting for the low outflows of FDI from China shown in Figure 6.

In our procedure, we did not attempt to target direct measures of technological capital or transfers thereof. Measuring intangibles such as technological capital can be difficult. Nevertheless, if we can treat counts of new patents as a proxy for inflows of technological capital, we can use the earlier patent data to make some suggestive calculations related to goodness of fit.

Specifically, we use the patent data in Table 1 from the automobile industry, and we examine the consistency of this data with our estimate of the equilibrium transfer rate from QPQ, which we denote here by $h_{c}\left(q_{c}\right)$. Let $\sum_{j \neq c} M_{c t}^{j}$ be the total foreign multinational technology capital in China at time $t$, and let $\sum_{j \neq c} p_{c t}^{j}$ be the number of new patents at time $t$ of the multinationals. Assuming a proportional factor $\varphi$ between Chinese patents and new units of technology capital, the stock of multinational technology capital evolves according to

$$
\sum_{j} M_{c, t+1}^{j}=\left(1-\delta_{M}\right)\left(1-h_{c}\left(q_{c}\right)\right) \sum_{j} M_{c t}^{j}+\varphi \sum_{j} p_{c t}^{j}
$$

Note that we are assuming that $q_{c}$ is the same for all foreign multinationals in China. The technology capital transferred in period $t$ equals

$$
\varphi p_{c t}^{T}=\left(1-\delta_{M}\right) h_{c}\left(q_{c}\right) \sum_{j} M_{c t}^{j}
$$


In a steady state, $\sum_{j} M_{c t}^{j}$ grows at the rate of total output $\gamma_{Y}$. Using this fact and taking ratios, we can eliminate $\sum_{j} M_{c t}^{j}$ and obtain the following equation for the ratio of transferred patents to patents by multinationals:

$$
\frac{p_{c t}^{T}}{\sum_{j} p_{c t}^{j}}=\frac{\left(1-\delta_{M}\right) h_{c}\left(q_{c}\right)}{1+\gamma_{Y}-\left(1-\delta_{M}\right)\left(1-h_{c}\left(q_{c}\right)\right)} .
$$

If we substitute an estimate of the ratio of patent counts, and if we substitute the depreciation rate $\delta_{M}=0.08$, and the growth rate of output $\gamma_{Y}=0.03$ from the model, we can back out $h_{c}\left(q_{c}\right)$ and check its consistency with our estimates. We consider two estimates for the patent ratio. In the first, we treat all patents of Chinese firms with joint venture partners as transferred. In this case, the ratio of patent counts is $1,078 / 14,500$, and our estimate of the QPQ transfer rate is $h_{c}\left(q_{c}\right)=0.01$. Suppose next that even the independent firms take technology from the multinationals. ${ }^{47}$ If we include both the independent and joint venture firm patents as transferred, then the ratio of patent counts is $4,355 / 14,500$, and the estimate of the QPQ transfer rate is $h_{c}\left(q_{c}\right)=0.051$. These rough calculations yield a range of estimates that brackets the estimates in Table 5 in 1995 and beyond for the equilibrium QPQ transfer rate. ${ }^{48}$

\subsection{The Global Distribution of Technology Capital}

We now use the model to examine how the global distribution of technology capital has changed over time. In Table 6 we report each country's share of the world's accumulated nontransferred technology capital $\left(M_{i}^{i} / \sum_{i} M_{i}^{i}\right)$. Note that China lags behind all other countries including BRI. The model predicts that in 1990, China's nontransferred technology capital level was tiny, a 0.1 percent share. By 2010, its world share of nontransferred technology capital had increased 60-fold, to 6.1 percent. Nevertheless, this amount is still less than half of Japan's level, even though China's total GDP is larger than Japan's in 2010. Although the United States, Western Europe, and Japan have lost ground over the period, together they still account for more than 70 percent of world technology capital in 2010.

Table 7 compares nontransferred and transferred capital-output ratios for China and BRI, the two regions that require QPQ transfers in the model. For both regions, the ratio of transferred capital to GDP is much larger than the ratio of nontransferred capital to GDP. In 1990, technology capital transfer to China is roughly 0.83 times GDP from foreigners doing FDI in China. This ratio falls with the rapid growth in China's GDP, but by 2010 the transferred capital stock is still

47 One example is based on a lawsuit filed by General Motors against the independent firm Chery Automobile Company, claiming the Chery QQ was a clone of GM's Chevrolet Spark. According to news reports, analysts projected that "the QQ will not be sold in the United States, owing to the G.M. litigation" (see Chris Buckley, "Enter the Chinese Dragon, Now Bearing Minicars," New York Times, January 7, 2005, http://www.nytimes.com/2005/01/07/business/worldbusiness/07auto.html? $\_0$ ).

48 If we use the second half of the sample, with patents published during 2008-2010, the estimated range is $[.014, .09]$. 
large relative to the capital accumulated by Chinese multinationals, by roughly a factor of 2 (or 0.35/0.16). The trends in these ratios are less dramatic in BRI because these countries did not grow as rapidly as China over the period. BRI's transferred capital stock is 0.49 in 1990 and falls to 0.30 in 2010 .

Having first looked at the technology capital-output ratios of China and BRI in Table 7, we next examine the two margins that affect inflows of technology capital into China and BRI from the advanced countries. The first margin is the intensity margin $q$ shown in the first and third columns of Table 8. Without the QPQ tax, firms set $q=1$. With QPQ, firms from the advanced countries set $q$ substantially less than one in all years. This intensity level increases and then decreases. For example, in the case of FDI in China, the intensity level increases from 0.21 to 0.41 over the years 1990-2000, reflecting the growth in productivity that increases the incentives to bring in technology capital. The decline from 0.41 to 0.35 over the period 2000-2010 stems from the increase in the QPQ tax schedule, which is consistent with the time pattern of the share of inflows to China from the advanced countries.

A second margin at play - the extensive margin - is the volume of the technology capital from advanced countries that is not yet transferred. In the second and fourth columns of Table 8, we report the share of technology capital that is not yet transferred, that is, $\sum_{j} M_{i t}^{j} /\left(\tilde{M}_{i t}+\sum_{j} M_{i t}^{j}\right)$, where the $j$ in the sums are the United States, Western Europe, and Japan, and $i$ is either China or BRI. This measure reflects the share of knowledge that foreign firms still have available for use in China or BRI, which, along with the intensive margin, is a key determinant of FDI flows. Note, in particular, the results in the second column of Table 8. The share of technology capital not transferred from advanced countries to China fell from 86 percent to 77 percent between 2000 and 2010, a decline of 9 percentage points. This decline reflects the cumulative effect of transfers taking place over the decade. Thus, the cumulative transfer channel is a significant part of the story of what happened to inflows from the advanced nations to China over the period, working in the same direction as the intensity channel. The same is true for BRI.

In this section, we have used observed patterns of growth and international capital flows to pin down the model's parameters and from there have examined properties of the model economy. We turn next to policy analysis.

\section{Policy Analysis}

In this section, we use our quantitative model to study the effects of quid pro quo policy. As our baseline, we use the model calibrated to the actual policy choices derived in the previous section. We simulate the effects of counterfactual alternative policy choices beginning in 1991, comparing transitions from the same initial state in 1990. We examine how alternative policies 
affect the welfare of the various countries, determine the quantity of technology capital created by the various countries, and identify which countries own the technology capital and where they use it. The first part of this section considers the effects of unilateral changes in QPQ by China. The second part compares QPQ with a tax on profits. The third part evaluates the effects of multilateral changes in QPQ policy.

\subsection{Unilateral Changes in China's Quid Pro Quo}

Our first exercise examines the consequences of China's elimination of QPQ beginning 1991. Formally, assume $h_{c t}^{j}(q)=0$ in China for all source countries $j$, with all other policy choices remaining at the baseline settings. The policy change is unanticipated, so the initial state variables in 1990 for the counterfactual exercise are the same as in the baseline. Panel A of Table 9 presents the results. In the first row, we report the welfare effects of the actual policy relative to the alternative. The welfare measure is the percentage change in the path of consumption that would be necessary to compensate individuals in the various countries under the counterfactual, in order to leave them indifferent to the actual policy.

For China, the welfare benefit of the actual QPQ policy relative to eliminating it in 1991 is equivalent to a 4.69 percent increase in consumption. This is a significant welfare effect and is to be expected as a consequence of three key findings from Section 5. First, in the calibrated model, the implied QPQ transfer rates are significant. Second, a significant fraction of technology capital used in China is coming from the advanced countries. Based on these two results, we know that high QPQ tax levels are being applied to a relatively large base, and we can expect China to benefit in the usual way that a country levying a high tax on a large base can benefit. The third key result in the baseline model relevant here is that even though China has become more open in recent years, significant barriers to foreigners remain. In formal terms of the model, even by 2010, the openness parameter is significantly less than one, $\sigma_{c, 2010}=0.81$. When technology capital is transferred from a foreign firm to a domestic firm, barriers are overcome, which creates welfare gains.

Although the actual QPQ policy is better for China than having no QPQ requirements, it is not necessarily the best QPQ policy for China. Indeed, we have verified that China's welfare is strictly increasing in higher levels of QPQ, evaluated locally at the actual policy. ${ }^{49}$ This finding is not surprising, because if we were to model China's policy choice, we would take into account an additional consideration left out of our model. In particular, at higher levels of QPQ, China would have a harder time claiming that it is abiding by international agreements, and therefore the likelihood of punitive sanctions would increase. Based on this consideration, we would expect

49 We verify this by increasing the QPQ cost parameters by a small amount in all periods. 
China's QPQ level to be on the upward-sloping portion of a Laffer curve, and indeed that is the case.

Next we consider the impact of China's QPQ policy on the advanced nations. The effect on their welfare is obviously negative, since QPQ works like a tax imposed by China on these countries. The magnitude of this impact depends on the importance of China as a destination market for technology. If the Chinese market were negligible, the welfare effect of any kind of taxation for access to the Chinese market would be negligible. The significant finding in Table 9 is that the Chinese market is now large enough such that the welfare effect of China's QPQ policy is nonnegligible. In particular, the technologically advanced countries, namely, the United States, Western Europe, and Japan, are harmed by China's use of QPQ at rates in the range of -0.32 to -0.45 percent of consumption.

In the second row of Panel A in Table 9, we report the nontransferred capital ratio, defined as the 2010 baseline level of technology capital stock developed by domestic firms, namely, $M_{i}^{i}$ for all $i$, relative to the stock under the alternative policy. We condition on the stock in the home country because there are no QPQ requirements on domestic firms, and therefore the measure includes only technology capital that is internally developed and does not include transfers through QPQ. In the third row of Panel A in Table 9, we report the total capital ratio. This ratio sums transferred and nontransferred capital in the home country for 2010, and analogously, takes the ratio under the actual policy relative to the alternative policy. For the advanced countries, no transfers are received in the actual or the alternative policy, so the nontransferred capital ratio is identical to the total capital ratio. Examining these ratios for the advanced countries, we see that because of China's QPQ policy, technology capital stocks in the advanced countries are lower by 4 percent or more. By 2010, China's economy is large enough such that the effective tax on multinational technology capital investment through China's QPQ policy significantly affects the incentives to make these investments in the first place.

Next we consider the effects of QPQ on technology stocks in China. The nontransferred capital ratio is only 0.43. That is, because of China's QPQ policy, transferred capital substitutes for nontransferred capital, and China accumulates nontransferred stocks at a rate that is less than half of what it would be without QPQ. In contrast, the total capital ratio is 1.46. That is, when we take into account transfers through QPQ, China ends up owning 50 percent more technology capital in China by 2010 than it otherwise would. Note that rents from transferred capital are already included in the welfare measure on the first line in Panel A. However, suppose that beyond these rents that are already accounted for, China obtains additional intangible benefits from its ownership of the technology capital used domestically. These benefits might include those related to the military and national defense or even benefits simply related to national pride. Indeed, 
China has articulated an explicit policy goal of having self-owned innovation, as discussed earlier in Section 3. Our results show that China's use of QPQ has furthered that aim.

The last issue to address in this first exercise is what happens with BRI. For our baseline model, we assume that BRI imposes the same QPQ policy as China. In the counterfactual, China unilaterally eliminates QPQ, and BRI's use of QPQ remains at the baseline level. We see in Panel A of Table 9 that BRI is worse off when China also imposes QPQ because this policy induces advanced nations to invest less technology capital, meaning that there is less for BRI to appropriate. Note, however, that the particular assumptions we make regarding the QPQ policy in the BRI countries is not important to our conclusions.

In Panel B of Table 9, we consider an alternative counterfactual, one in which both China and the BRI eliminate QPQ beginning in 1991. The effects on China's welfare and capital stocks are very similar to the original counterfactual in Panel A: the welfare gain of QPQ policy for China is large, close to 4.4 percent, and the nontransferred capital ratio is small, about 0.44 percent. The welfare losses to the advanced countries are about twice as large because both China and BRI are large countries and have a significant impact on global investment decisions. In Section 7, we also consider an alternative economy in which BRI does not impose QPQ in the baseline or the counterfactual, and we obtain results that are very similar to those shown in Panel A.

\subsection{Comparison with a Tax on Profits}

In our baseline model, multinational firms from advanced nations face two different taxes for bringing technology capital to China. The first, QPQ, is a tax paid in units of transferred technology capital. The second, a tax on profits, is levied on the profits of foreign affiliates in China and paid in units of the consumption good. The profits tax corresponds to parameter $\tau_{p, i t}$ in equation (4.1) and is set equal to 33 percent of profits in the baseline model, as explained in Section 4. In this subsection, we contrast the effects of these two different types of taxes. We consider an experiment in which the tax on profits for the advanced countries is set to zero beginning in 1991, and we leave everything else, including QPQ, the same. Domestic firms are assumed to pay the 33 percent profits tax, as are multinationals from other countries besides the advanced nations; this assumption is held fixed in the exercise. Thus, in our analysis, we are examining the effects of differentially changing the profits tax rate faced by multinationals from the advanced nations. We lower the tax to zero not because this rate corresponds to any actual policy under consideration but rather to compare the effects with the first counterfactual that sets QPQ to zero. The exercise helps to illuminate how the model works. ${ }^{50}$

50 Note, however, that China actually lowered tax rates on the profits of foreign firms as an incentive for companies to invest in China. We discuss the details further in Section 7. 
The results of our exercise are tabulated in Panel $\mathrm{C}$ of Table 9. The welfare effects of a profits tax (first row of Panel C) have the same signs as the welfare effects of QPQ (first row of Panel A). In particular, the countries that are subject to the tax lose under either type of tax, although the magnitude of the QPQ effects is on the order of three or four times the profits tax effects. For example, under the baseline, the United States loses 0.18 percent in consumption compared with the no profits tax effects, and loses 0.45 percent in consumption compared with the no QPQ effects. The taxing country gains: China's gain is 1.0 percent from the tax on profits and 4.7 percent from QPQ. Finally, the remaining country groups, BRI and ROW, experience an indirectly negative impact from either type of tax because of the negative impact on investment in technology capital by advanced countries.

So far, our discussion has focused on the ways in which a tax on profits and QPQ policy have qualitatively similar effects. We now direct the discussion to capital ratios in China, and here policies are quite different. Because of the profits tax, nontransferred capital in China increases by 4 percent, substituting for declines in investment by the advanced countries. This result contrasts with the QPQ policy, where nontransferred technology capital in China falls by more than half, since transferred capital substitutes for nontransferred capital. Next, note that total technology capital (which includes transfers) is higher by only 2 percent under a profits tax but almost 50 percent higher with QPQ. That is, a tax on profits does not contribute to China's goal of self-owned innovation in the same way that QPQ does. ${ }^{51}$

\subsection{Multilateral Changes in QPQ Policy}

Countries have a unilateral incentive to impose at least some level of QPQ for the usual optimal taxation considerations. In this final subsection, we discuss the welfare effects of multilateral changes in QPQ policy. Although a country may benefit from its own QPQ policy, it is harmed by the QPQ of other countries, and these offsetting effects may or may not cancel out each other.

Panel D of Table 9 tabulates the effects of a counterfactual policy in which the United States, Western Europe, and Japan all adopt the same QPQ policy as China, beginning in 1991. Notice the negative signs on the welfare numbers for the three advanced economies, meaning that the baseline yields lower returns than the counterfactual. That is, the advanced nations gain by multilaterally initiating QPQ against each other and against China and BRI.

If we compare Panels B and D, however, we find that the United States and Western Europe have incentives to push for global investment agreements that limit the use of QPQ multilaterally. To see this result, start with the welfare numbers in Panel B - a comparison of the baseline with

51 Another difference is found in predicted capital flows. Assuming that China is only taxing foreign affiliate profits and not implementing a QPQ policy, the model overpredicts outward FDI flows as shown in Figure 6. 
QPQ with the alternative without QPQ - and subtract the welfare numbers in Panel D - the baseline relative to the alternative with the United States, Western Europe, and Japan also adopting QPQ. The baseline cancels, and we are left with a comparison of two environments: one with all countries (except ROW) employing QPQ and one with no countries employing QPQ. The net welfare effect for the United States equals $-.96-(-.74)=-.22$. That is, the United States is a net loser when QPQ is adopted in this broad multilateral fashion, as is Western Europe. In contrast, the figures for China and BRI are $4.37-1.98=2.39$ and $4.61-2.30=2.31$, so both are net winners. The intuition for the asymmetry is clear: China and BRI originate disproportionately less technology capital than the advanced economies, so China and BRI do relatively better under a regime in which technology capital is effectively taxed through QPQ, even multilaterally. Since the United States and Western Europe are net losers from multilateral QPQ, they push for limits on the use of QPQ, such as those set by the WTO.

Finally, we note that the effects of multilateral QPQ in Japan are quite different from those in the United States and Western Europe. ${ }^{52}$ This result arises from differences in the degree of openness. In the model, for 2010, the degree of openness parameter for Japan $\left(\sigma_{i t}\right)$ is equal to 0.730 (as shown in Table 4) which is actually lower than China's level (0.811) and significantly lower than the levels for the United States and Western Europe (0.870 and 0.858, respectively). If Japan is able to appropriate foreign technology and operate it without these extensive barriers, it obtains significant welfare gains.

\section{Robustness}

In Table 10, we investigate the sensitivity of our main results to alternative specifications of the model. In each case, we reparameterize the model, following the method of Section 5, choosing levels of TFPs, degrees of openness, and the QPQ parameters to match trends in real per capita GDPs and inward FDI flows. In all cases, we confirm the main findings from the baseline model.

The first alternative specification allows for knowledge spillovers that depend on the level of technology capital deployed within a country. The results are shown in the second column of Table 10 under the heading "Add Knowledge Spillovers." As noted in Section 2, spillovers receive much attention in discussions of the effects of FDI, so it is useful to examine how incorporating spillovers affects our results. Formally, define $\mu_{t}^{j}$ as the total level of technology capital deployed in country $j$ from all sources,

$$
\mu_{t}^{j}=\left\{M_{j t}^{j}+\tilde{M}_{j t}+\sigma_{j t}^{\frac{1}{\phi}} \sum_{\ell \neq j} q_{j t}^{\ell} M_{j t}^{\ell}\right\} /\left(1+\gamma_{Y}\right)^{t},
$$

52 Japan is also quite different from China because of its military alliance with the United States following World War II. It is likely that some technology transfer, which is not modeled here, was needed to secure peace in the Pacific region. 
where $\gamma_{Y}$ is the trend growth rate of output. Note that we are defining this level as net of the barrier $\sigma_{j}$ faced by foreign firms and net of the intensity choice $q_{j}$. Let the production function for new technology capital be given by $\left(\mu_{t}^{j}\right)^{\theta} X_{M, t}^{j}$, which substitutes for $X_{M, t}^{j}$ in equation (4.4). The parameter $\theta$ governs the degree of spillover, and we get back to the baseline model with $\theta=0$. For our robustness exercise, we set $\theta=.05$, a significant magnitude of spillover. ${ }^{53}$ Our results with spillovers included are shown in the second column of Table 10. These results should be compared with the baseline results in the first column. Note that China's implied share of 2010 world nontransferred capital is virtually the same with spillovers as in the baseline, 5.9 percent versus 6.1 percent, whereas levels of technology capital (relative to GDP) are higher in the spillover case. With spillovers, the price of investment decreases both inside and outside of China, and there is little change in where innovation occurs, only in how much. Next, note at the bottom of Table 10 that the welfare effects of unilateral QPQ by China are barely affected by the inclusion of spillovers.

The second alternative specification, shown in the third column of Table 10 and labeled "Transfer TFP Discount," allows for discounting to take place through the transfer process, that is, $\zeta<1$. In the 1960s and 1970s, the view was that development of so-called third world countries could be achieved by large transfers of technology from the first world. In more recent decades, the broadly recognized view is that local firms in developing countries may not have the capacity to fully absorb transferred technologies (see UNCTAD, 2001, for a discussion). To incorporate this force here, we consider a version of the model with $\zeta=0.9$, that is, a 10 percent TFP discount on transfer. (Again, we reparameterize the rest of the model to match GDPs and FDI flows.) Note in particular the policy results at the bottom of the table. Not surprisingly, transfer discounting attenuates China's welfare gain from unilateral use of QPQ. In fact, the welfare gain to China is about 90 percent of the original welfare gain (4.24 versus 4.69). China does more of its own research under QPQ in this specification (the nontransferred capital ratio goes from 0.43 to 0.50 ), because it appropriates less, net of the discount. But note that the counterfactual policy effects on U.S. research is unchanged compared with the baseline case. Although not reported here, the story is similar for Western Europe and Japan. The welfare loss to the United States of China's unilateral use of QPQ is somewhat smaller in absolute value than in the baseline specification. (When appropriators are less productive, it works to the advantage of the foreign affiliates with whom they compete.) Nevertheless, taking into account the productivity discounting from transfer makes more of a difference for China than for the other countries. ${ }^{54}$

53 For example, Ciccone and Hall (1996), a classic reference on spillovers, estimates a spillover parameter of approximately this magnitude. Quantifying knowledge spillovers continues to be an important area of research. See, for example, Atkeson and Burstein (2011), research surveyed by Hale and Long $(2011,2012)$, and and the work of Bloom, Schankerman, and Van Reenen (2013).

54 We have also verified that even with the reduced benefit from technology transfer in this alternative specification, China continues to prefer multilateral imposition of QPQ to no QPQ. 
Our third alternative specification follows up on our previous discussion on outright expropriation. In Section 4.2, we noted the equivalence in fitting the facts between $(i)$ our model with an upward-sloping required transfer function $h(\cdot)$, and openness parameters $\sigma_{i, t}$ that vary with destination $i$ but not source $j$, and $(i i)$ an alternative version of the model with a perfectly flat required transfer function, and a generalization of the assumptions on the openness parameters $\hat{\sigma}_{i, t}^{j}$ to allow them to vary with source. Although both versions are equivalent in fitting the data, they differ in the policy consequences of setting the transfer function parameters to zero. The reason is that in the baseline model, the intensity variable $q$ changes, whereas in the alternative, it remains fixed. These differential effects are seen by comparing the baseline case in the first column of Table 10 with the case labeled "Theft and Disparate Openness" in the fourth column. The qualitative effects are similar, and, interestingly, the magnitudes are surprisingly close. In the alternative model, adopting QPQ has a 5.54 percent effect on China's welfare compared to the baseline case, where the difference is 4.69 percent. The intuition for the difference is that when transfers are imposed in the baseline model, reductions in intensity $q$ offset China's welfare gain. In contrast, in the alternative specification with outright expropriation, offsetting reductions in intensity do not take place. (There is no point in lowering $q$ if the amount extracted does not depend on it.) Turning to the effects on the United States, we see that the welfare effect of changing policy is a quarter percent in the alternative specification, compared with half a percent in the baseline. When forced transfers are eliminated in the baseline, foreign affiliates respond by increasing intensity, thereby magnifying the difference in foreign affiliate welfare.

The next two robustness exercises concern assumptions about how policies are assumed to change over time. In the baseline model, we assume that tax rates on corporate profits are fixed over time. China actually lowered rates, in part to attract greater foreign investment. The fifth column in Table 10, labeled "China's Tax Rate Lowered," shows the results if we lower the tax rate on profits in China from 33 percent to 25 percent, with most of the decline occurring after 2005 as observed. The results are nearly the same as in the baseline model, although the model predicts a slightly higher share, namely 8.0 percent, of world nontransferred capital for China in 2010, because lower taxes cause an increase in productive activity in China. We view this result as an upper bound because the rates of the other countries are fixed in this simulation. If we allow tax rates in other countries to vary as well, the model statistics would be even closer to the baseline, since all countries in our sample have seen some fall in corporate tax rates.

In the baseline model, we allow QPQ policy to vary over time. The exercise illustrated in the sixth column in Table 10, labeled "Time Invariant QPQ," shuts down this variation, requiring the time series $\bar{h}_{t}$ to be fixed at its 1990 level. Although the QPQ policy function is fixed, in the alternative specification, the equilibrium intensity level $(q)$ increases over time. Because of the convexity of the policy function, equilibrium transfer rates also increase, although the increase is 
less than in the baseline. (In the baseline, the transfer rate $h(q)$ starts at 0.2 percent and rises to 4.4 percent by 2010 . The alternative starts at the same rate, 0.2 percent, but rises to only 3.4 percent.) With less QPQ in 2010, there is more innovation in China, greater outward FDI, and lower welfare gains to China from unilateral QPQ. Nevertheless, the differences in magnitudes between the alternative specification and the baseline are quantitatively small.

Finally, in the baseline model, we assume that China and BRI both impose QPQ policies with identical parameters. This exercise, illustrated in the last column of Table 10, labeled "No QPQ in BRI," assumes instead that the BRI countries are similar to the advanced countries in that they have zero QPQ. The difference in China's welfare gain due to QPQ between this specification and the baseline is negligible.

In Holmes, McGrattan, and Prescott (2014) we report the results of additional sensitivity analyses, verifying that our results are robust to alternative country groupings and model parameterizations. The alternative country groupings we consider are: ( $i)$ Korea is included with Japan rather than ROW because of the recent rise in Korean high technology industries; (ii) ROW is eliminated to quantify various assumptions about the differences between ROW and the advanced countries made in the baseline model; and (iii) BVI and the Cayman Island net inflows to China are included with the advanced country flows to check our baseline assumption that flows from these tax shelters are simply round-tripping on the part of Chinese multinationals. ${ }^{55}$ We also vary

the parameters listed in Table 2 and the elasticity of the quid pro quo cost function, $h_{i t}^{j}(q)$. In all cases, we find that China's quid pro quo policy has had a significant impact on global innovation and welfare, and we find that the quantitative predictions are hardly affected.

\section{Summary}

This paper assesses the economic impact of China's quid pro quo policy, which makes technology capital transfer a requirement for market access. Analysis of Chinese patent data indicates that the terms of quid pro quo arrangements are such that transferred property rights apply inside China, not outside. We incorporate the policy into a quantitative, multicountry general equilibrium model and find a negative effect on advanced country welfare from the policy, approximately equal to 0.4 percent of consumption. China's economy is now large enough that its policies have significant effects on $R \& D$ decisions throughout the world. China gains significantly from the policy - almost 5 percent of consumption - and China prefers to follow it, even if other countries also adopt the policy.

Although the model is detailed in several respects - in particular, it is capable of generating the

55 For more on the measurement complications with round-tripping, see Xiao (2004) and Sutherland and Matthews (2009). 
equilibrium transition of a macro model with six economies having significantly different policiesa variety of simplifying assumptions have necessarily been made. These assumptions include an aggregate technology with a single consumption good with no scope for "wool for wine" trade. As a conceptual matter, it is straightforward to generalize the model to multiple industries, generating trade in consumption goods based on comparative advantage. Such an extension would allow for industry-specific technology capital and for technology and policy parameters to vary across industries. Indeed, regulation of FDI in China does vary by industries. Our paper hints at this variation, allowing quid pro quo parameters to be high for an advanced economy like the United States, with its high-technology industries such as motor vehicles and aerospace, which are heavily regulated in the actual policy. An explicit industry-level analysis would be an interesting topic for future work but would require enhanced data sets. There also remains the issue of how productivity changes as technology is transferred. Our baseline model assumes that innovators and appropriators are equally productive. We explored a 10 percent transfer discount in our robustness analysis. The transfer discount was set arbitrarily, however, and further work on this potentially significant issue is warranted.

In our model, multinational firms bring technology to other countries through FDI. Earlier, we noted that policies that block FDI entirely and require technology inflows to work through licensing deals can also include a quid pro quo element. In fact, we can take our model and restructure the contracts, and then reinterpret the outcomes as licensing rather than as FDI. In this case, measured technology flows will show up as royalties in the trade statistics instead of FDI in the capital accounts. Future work could extend our analysis to include these licensing deals, and an interesting application is to explore the growth experiences of Japan and Korea, which have both relied heavily on licensing.

Finally, future work could explore policies for regulating the use of QPQ. For example, in accordance with the WTO principle of reciprocity, one potential policy response of a country like the United States to China's actions is to impose an equivalent level of QPQ on Chinese FDI into the United States. The model can be used to recalculate China's incentive under such a policy. 


\section{A. Data Sources}

In this appendix, we report on our data sources. All of our data and computer codes are available at our website, www.minneapolisfed.org/research/sr/sr486.html.

Three main sources of patent data are used in the analysis of Section 3. For the published patents in China, we used data on individual patents obtained from patent searches at the State Intellectual Property Office of China (SIPO). The original data set includes all published invention and utility patents over the period 1985 to 2010 (3.6 million published patents). We restrict attention to invention patents published over the period 2005-2010 (1.4 million published patents). For U.S. published patent applications, we obtained the raw text files for published U.S. patent applications at the Google Bulk Patent Download site (www.google.com/googlebooks/uspto.html). Data are provided at this site through an arrangement between Google and the U.S. Patent and Trademark Office. Applications were first published in 2000. Our data begin there and extend through 2012, and include 3.3 million published applications. For the WIPO published patent applications, we obtained WIPO applications from patent searches at the WIPO web site (patentscope.wipo.int/search/en/search.jsf). Our data include patent years 1999-2012 (1.8 million applications).

Data on the top 500 foreign affiliate sales discussed in Section 3 are provided by China's Ministry of Commerce and were downloaded at www.fdi.gov.cn/pub/FDI. The files posted at our website contain the sales volumes and names of the top 500 foreign affiliates doing business in China. We used the files for 2006 and 2007. We used Google Translate to translate affiliate names.

The main data used for the analysis of our quantitative model in Section 5 are populations, GDPs, FDI flows, and estimates of profits tax rates. The source of data on country populations and GDPs is the World Bank's World Development Indicators (WDI) database (World Bank, 1960-2012). Specifically, we use total population (sp.pop.totl), GDP in current U.S. dollars (ny.gdp.mktp.cd), and GDP at purchasing power parity in constant 2005 international dollars (ny.gdp.pcap.pp.kd). ${ }^{56}$

Several sources are used for foreign direct investments. For China, data on inward FDI (actually utilized) are available for the period 1990-2010 by source country from the China Statistical Yearbook (China National Bureau of Statistics, 1990-2012). Outward FDI data by host country are available starting in 2003 from the China Commerce Yearbook (China Ministry of Commerce 2003-2012). Prior to 2003, we use total FDI flows reported by the United Nations in their UNCTADstat and China's 2003 outward FDI stocks to estimate the bilateral flows. Specifically, we construct pro rata shares of the total flow, with the shares equal to the ratio of a host country's stock in 2003 relative to the total outward FDI stock from China.

To construct FDI for China, we include inward and outward flows to and from the provinces of Hong Kong, Macao, and Taiwan and subtract out any flows between the provinces. Hong Kong's Census and Statistics Department publishes data on inward FDI by major investor country and

56 The WDI does not publish data for Taiwan and has missing years for some countries. We use the International Monetary Fund's World Economic Outlook Database (IMF, 1990-2012) and the United Nation's National Accounts Main Aggregates Database (UN, 1990-2012) to fill in the missing data. 
outward FDI by major recipient. The data are available starting in 1997. As with China, we use stocks for the first year data are available and total FDI flows from UNCTAD to construct estimates for the pre-1997 bilateral flows. As before, the estimates are found by multiplying the total flow reported by UNCTAD by the ratio of a country's stock of FDI in 1997 to the total stock. We do this for flows in and out of Hong Kong. Macao's Statistics and Census Service publishes bilateral FDI statistics starting in 2001. The flows and stocks are small relative to the other Chinese provinces, especially at the start, and therefore we simply assume they are zero for the period 1990-2000. Taiwan does not report bilateral flows. Where available, we use statistics of bilateral FDI flows to and from Taiwan reported by other countries, and we use UNCTAD data for Taiwan's FDI totals.

For OECD countries other than the United States, we use FDI statistics, which are available for their partner countries, reported to the OECD by member countries (see OECD 1990-2010). As in the case of China, we subtract out any FDI flows between the European countries when constructing FDI statistics for Western Europe. The United States data come directly from the U.S. Bureau of Economic Analysis because there is typically a lag in reporting revised data to the OECD.

We do not have all bilateral flows for the combined entities BRI or ROW, but do have total inward flows. The source of the total inward flows is UNCTADstat. Without bilateral flows, it is not possible to subtract out flows to and from countries within a group of countries. Instead, we construct population-weighted ratios of FDI to GDP, which we interpret as the typical ratio for countries in that group. Then, to get total FDI flows, we multiply the weighted ratio by total GDP for the group.

The main source of data for tax rates on profits is the OECD Tax Database (OECD 19902012). For non-OECD countries, we use estimates compiled by the accounting firm KPMG International (1993-2012). 


\section{References}

AMERICAN CHAMBER OF COMMERCE IN CHINA (AmCham China) (2013), China Business Climate Survey Report, www.amchamchina.org.

ATKESON A. and BURSTEIN, A. (2011), "Aggregate Implications of Innovation Policy" (Working Paper, University of California, Los Angeles).

BACKUS, D. K., KEHOE P. J., and KYDLAND, F.E. (1992), "International Business Cycles," Journal of Political Economy, 100, 745-775.

BARNES, W. S. (1979), "Technology Transfer Rules in Latin America: A Study in Comparative Law," Boston College International and Comparative Law Review, 3, Article 2.

BLOOM, N., SCHANKERMAN, M., and VAN REENAN, J. (2013), "Identifying Technology Spillovers and Product Market Rivalry," Econometrica, 81, 1347-1393.

BRANSTETTER, L. and FOLEY, C. F. (2010), "Facts and Fallacies about U.S. FDI in China," in China's Growing Role in World Trade, edited by R. C. Feenstra and S.-J. Wei (Chicago: University of Chicago Press).

BRANSTETTER, L. and LARDY, N. (2010), "China's Embrace of Globalization" (NBER Working Paper 12373).

BRANSTETTER, L. and FISMAN, R., FOLEY, C. F., and SAGGI, K. (2011), "Does Intellectual Property Rights Reform Spur Industrial Development?" Journal of International Economics, 83, 27-36.

BURStEIN, A. T. and MONGE-NARANJO, A. (2009), "Foreign Know-How, Firm Control, and the Income of Developing Countries," Quarterly Journal of Economics, 124, 149-195.

CHINA MINISTRY OF COMMERCE (2003-2012), China Commerce Yearbook, www.yearbook. org.cn.

CHINA MINISTRY OF COMMERCE (2007), Catalogue for the Guidance of Foreign Investment Industries, www.fdi.gov.cn.

CHINA NATIONAL BUREAU OF STATISTICS (1990-2012), China Statistical Yearbook, www. stats.gov.cn.

CHINA STATE COUNCIL (2006), "The National Medium- and Long-Term Program for Science and Technology Development (2006-2020): An Outline," www.gov.cn.

CHINA SUPREME PEOPLE'S COURT (1999), Contract Law of the People's Republic of China, en.chinacourt. org.

CICCONE, A. and HALL R. (1996), "Productivity and the Density of Economic Activity," American Economic Review, 86, 54-70. 
DEFEVER, F. and RIAÑO, A. (2012), "China's Pure Exporter Subsidies" (Working Paper, University of Nottingham).

EATON, J. and KORTUM, S. (1999), "International Technology Diffusion: Theory and Measurement," International Economic Review, 40, 537-570.

EUROPEAN COMMISSION (2011), "Technology Transfer to China: Guidance for Businesses," China IPR SME Help Desk, www.china-iprhelpdesk.eu.

EUSME CENTRE (2014), "How to Successfully Transfer Your Technology: Impact on SMEs with a Focus on China," Webinar, May 20.

FAJGELBAUM, P., GROSSMAN, G. M., and HELPMAN E. (2014), "A Linder Hypothesis for Foreign Direct Investment" Review of Economic Studies, forthcoming.

GROSSMAN, G. M., and HELPMAN E. (1991a), "Quality Ladders in the Theory of Growth," Review of Economic Studies, 58, 43-61.

GROSSMAN, G. M., and HELPMAN E. (1991b), "Quality Ladders and Product Cycles," Quarterly Journal of Economics, 106, 557-586.

HALE, G. and LONG C. (2011), "Are There Productivity Spillovers from Foreign Direct Investment in China?" Pacific Economic Review, 16, 135-153.

HALE, G. and LONG C. (2012), Foreign Direct Investment in China: Winners and Losers (Singapore: World Scientific).

HAO, J. (2012), "Intangible Investment in China Has Grown Rapidly-But Is It Efficient?" Chart of the Week, August 24, China Center for Economics and Business, The Conference Board.

HELPMAN, E. (1993), "Innovation, Imitation, and Intellectual Property Rights," Econometrica, 61, 1247-1280.

HELPMAN, E., MELITZ, M. J., and YEAPLE, S. R. (2004), "Export Versus FDI with Heterogeneous Firms," American Economic Review, 91, 300-316.

HOLMES, T. J., MCGRATtAN, E. R., and PRESCOTT, E. C. (2013), "Patent Data Appendix for Quid Pro Quo: Technology Capital Transfers for Market Access in China" (Research Department Staff Report 488, Federal Reserve Bank of Minneapolis).

HOLMES, T. J., MCGRATTAN, E. R., and PRESCOTT, E. C. (2014), "Technical Appendix for Quid Pro Quo: Technology Capital Transfers for Market Access in China” (Research Department Staff Report 487, Federal Reserve Bank of Minneapolis).

HONG KONG CENSUS AND STATISTICS DEPARTMENT (1997-2012), National Income and Balance of Payments, www. censtatd.gov.hk.

HORSTMANN, I. J. and MARKUSEN, J. R. (1992), "Endogenous Market Structures in International Trade (Natura Facit Saltum)," Journal of International Economics, 32, 109-129. 
HSIEH, C.-T. and KLENOW, P. J. (2009), "Misallocation and Manufacturing TFP in China and India," Quarterly Journal of Economics, 124, 1403-1448.

HULTEN, C. R. and HAO, J. X. (2012), "The Role of Intangible Capital in the Transformation and Growth of the Chinese Economy" (NBER Working Paper 18405).

INTERNATIONAL MONETARY FUND (IMF) (1990-2012), World Economic Outlook Database, www.imf.org.

KELLER, W. and YEAPLE, S. R. (2013), "The Gravity of Knowledge," American Economic Review, 103, 1414-1444.

KIM, J.-D. and HWANG, S.-I. (2000), "The Role of Foreign Direct Investment in Korea's Economic Development," in The Role of Foreign Direct Investment in East Asian Economic Development, NBER-EASE vol. 9, edited by T. Ito and A. O. Krueger (Chicago: University of Chicago Press).

KPMG International, 1993-2012, Corporate and Indirect Tax Rate Survey, www.kpmg.com.

LAI, E. L. C. (1998), "International Intellectual Property Rights Protection and the Rate of Product Innovation," Journal of Development Economics, 55, 133-153.

MACAO STATISTICS AND CENSUS SERVICE (2001-2012), Direct Investment Statistics, www. dsec.gov.mo.

MARKUSEN, J. R. (2001), "Contracts, Intellectual Property Rights, and Multinational Investment in Developing Countries," Journal of International Economics, 53, 189-204.

MARKUSEN, J. R. and VENABLES, A. J. (2000), "The Theory of Endowment, Intra-industry and Multi-national Trade," Journal of International Economics, 52, 209-234.

MASON, M. (1992), American Multinationals and Japan: the political economy of Japanese capital controls, 1899-1980, Cambridge, Mass.: Council on East Asian Studies, Harvard University.

MCCULLOCH, R. (1981), "Technology Transfer to Developing Countries: Implications of International," Annals of the American Academy of Political and Social Science, 458, 110-122.

MCGRATTAN, E. R. and PRESCOTT, E. C. (2009), "Openness, Technology Capital, and Development," Journal of Economic Theory, 144, 2454-2476.

MCGRATTAN, E. R. and PRESCOTT, E. C. (2010), "Technology Capital and the U.S. Current Account," American Economic Review, 100, 1493-1522.

MONTALVO, J. G. and YAFEH, Y. (1994), "A Microeconometric Analysis of Technology Transfer: The Case of Licensing Agreements of Japanese Firms," International Journal of Industrial Organization, 12, 227-244.

MORAN, T. H. (1999), Foreign Direct Investment and Development: The New Policy Agenda for Developing Countries and Economies in Transition (Washington, DC: Peterson Institute for International Economics). 
NATIONAL SCIENCE FOUNDATION (NSF) (2012), Science and Engineering Indicators 2012, www.nsf.gov.

ORGANISATION FOR ECONOMIC CO-OPERATION AND DEVELOPMENT (OECD) (19902010), "FDI Flows by Partner Country," OECD.StatExtracts, www.oecd.org.

ORGANISATION FOR ECONOMIC CO-OPERATION AND DEVELOPMENT (OECD) (19902012), OECD Tax Data- base, stats.oecd.org.

ORGANISATION FOR ECONOMIC CO-OPERATION AND DEVELOPMENT (OECD) (2000), OECD Patents by Technology, stats.oecd.org.

PRASAD, E. and WEI, S.-J. (2007), "The Chinese Approach to Capital Inflows: Patterns and Possible Explanations," in Capital Controls and Capital Flows in Emerging Economies: Policies, Practices, and Consequences, edited by Sebastian Edwards (Chicago: University of Chicago Press).

RAMONDO, N. (2014), "A Quantitative Approach to Multinational Production," Journal of International Economics, 93, 108-122.

RAMONDO, N., RAPPAPORT, V., and RUHL, K. J. (2012), "Horizontal versus Vertical Foreign Direct Investment: Revisiting Evidence from U.S. Multinationals" (Working Paper, University of California, San Diego).

RAMONDO, N. and RODRÍGUEZ-CLARE, A. (2013), "Trade, Multinational Production, and the Gains from Openness," Journal of Political Economy, 121, 273-322.

SHEA, D. (2012), "The Impact of International Technology Transfer on American Research and Development," Testimony: Committee on Science, Space, and Technology Subcommittee on Investigations and Oversight, December 5, United States House of Representatives.

SONG, Z., STORESLETTEN, K., and ZILIBOTTI, F. (2011), "Growing Like China," American Economic Review, 101, 196-233.

SUTHERLAND, D. and MATTHEWS, B. (2009), "'Round Tripping' or 'Capital Augmenting' OFDI? Chinese Outward Investment and the Caribbean Tax Havens" (Working Paper, University of Nottingham).

UNITED NATIONS (UN) (1990-2012), National Accounts Main Aggregates Database, unstats.un. org.

UNITED NATIONS (UN) (1990-2012), FDI Statistics Division on Investment and Enterprise, UNCTADstat, unctadstat.unctad.org.

UNITED NATIONS CONFERENCE ON TRADE AND DEVELOPMENT (UNCTAD) (1996), International Investment Instruments: A Compendium, vol. 1, Multilateral Instruments (Geneva: United Nations), United Nations Publication, UNCTAD/DTCI/30.

UNITED NATIONS CONFERENCE ON TRADE AND DEVELOPMENT (UNCTAD) (2001), 
Transfer of Technology (Geneva: United Nations), United Nations Publication, Sales No. E.01. II.D.33.

UNITED NATIONS CONFERENCE ON TRADE AND DEVELOPMENT (UNCTAD) (2003), Foreign Direct Investment and Performance Requirements: New Evidence from Selected Countries (Geneva: United Nations), United Nations Publication, Sales No. E.03.II.D.32.

UNITED NATIONS CONFERENCE ON TRADE AND DEVELOPMENT (UNCTAD) (2014), Bilateral FDI Statistics 2014 (Geneva: United Nations), unctad.org.

UNITED STATES INTERNATIONAL TRADE COMMISSION (USITC) (2010), "China: Intellectual Property Infringement, Indigenous Innovation Policies, and Frameworks for Measuring the Effects on the U.S. Economy," Investigation No. 332-514, USITC Publication 4199 (amended).

U.S. CONGRESS, OFFICE OF TECHNOLOGY ASSESSMENT (1987), "Technology Transfer to China," OTA-ISC-340 (Washington, DC: U.S. Government Printing Office).

U.S.-CHINA BUSINESS COUNCIL (2012a), USCBC 2012 China Business Environment Survey Results, www.uschina.org.

U.S.-CHINA BUSINESS COUNCIL (2012b), USCBC 2012 China Business Environment Survey Supplement, www.uschina.org.

VAN REENEN, J. and YUEH, L. (2012), "Why Has China Grown So Fast? The Role of International Technology Transfer" (Working Paper, London School of Economics).

WALSH, K. A. (1999), "U.S. Commercial Technology Transfers to the People's Republic of China," A Report to the Office of Strategic Industries and Economic Security, Bureau of Export Administration, www.bis.doc.gov.

WORLD BANK (1960-2012), World Development Indicators, data.worldbank.org.

WORLD INTELLECTUAL PROPERTY ORGANIZATION (WIPO) (2012), World Intellectual Property Indicators, 2012 edition, www.wipo.org.

WORLD INTELLECTUAL PROPERTY ORGANIZATION (WIPO) (2013), "WIPO Survey on Technology Transfer Agreements," Memorandum prepared by the Secretariat, December.

WORLD TRADE ORGANIZATION (WTO) (2001), Accession of the People's Republic of China, Decision of 10 November 2001 (WT/L/432, 01-5996), www.wto.org.

XIAO, G. (2004), "People's Republic of China's Round-Tripping FDI: Scale, Causes and Implications" (ADB Institute Discussion Paper No. 7). 
TABLE 1

Published Patent Applications in China for Large Foreign

Multinationals and Domestic Chinese Firms, 2005-2010

\begin{tabular}{|c|c|c|}
\hline Type of Applicant & $\begin{array}{l}\text { Number of } \\
\text { Patents }\end{array}$ & $\begin{array}{l}\text { \% Linked to U.S. or } \\
\text { WIPO Application }\end{array}$ \\
\hline & \multicolumn{2}{|c|}{ A. All Industries } \\
\hline Foreign multinational & 209,594 & 82.1 \\
\hline $\begin{array}{l}\text { Shared with Chinese partners } \\
\text { Exclusive }\end{array}$ & $\begin{array}{r}10,184 \\
199,410\end{array}$ & $\begin{array}{r}1.7 \\
86.2\end{array}$ \\
\hline \multicolumn{3}{|l|}{ Only patents first filed in China } \\
\hline Chinese firms & 585,650 & 4.7 \\
\hline $\begin{array}{l}\text { Top } 100 \text { domestic patenters } \\
\text { Not top } 100\end{array}$ & $\begin{array}{r}79,518 \\
506,132\end{array}$ & $\begin{array}{r}16.5 \\
2.8\end{array}$ \\
\hline \multicolumn{3}{|l|}{ Foreign multinational } \\
\hline $\begin{array}{l}\text { Shared with Chinese partners } \\
\text { Exclusive }\end{array}$ & $\begin{array}{l}10,075 \\
12,446\end{array}$ & $\begin{array}{r}1.5 \\
10.1\end{array}$ \\
\hline \multicolumn{3}{|c|}{ Foreign multinational, Chinese inventor and location } \\
\hline \multirow[t]{2}{*}{ Exclusive } & $\begin{array}{l}7,446 \\
2,113\end{array}$ & $\begin{array}{r}2.0 \\
10.6\end{array}$ \\
\hline & \multicolumn{2}{|c|}{ B. Automobile Industry } \\
\hline \multicolumn{3}{|l|}{ Foreign multinational } \\
\hline $\begin{array}{l}\text { Shared with Chinese partners } \\
\text { Exclusive }\end{array}$ & $\begin{array}{r}142 \\
14,500\end{array}$ & $\begin{array}{r}0.7 \\
85.0\end{array}$ \\
\hline \multicolumn{3}{|l|}{ Chinese firms } \\
\hline $\begin{array}{l}\text { Company has joint venture } \\
\text { Independent company }\end{array}$ & $\begin{array}{r}936 \\
3,277\end{array}$ & $\begin{array}{l}0.9 \\
7.4\end{array}$ \\
\hline
\end{tabular}

Note.-Authors' calculations are based on microdata on published patents in China. Patent counts include only invention patents. See Appendix A and Holmes, McGrattan, and Prescott (2013) for more details. 
TABLE 2

Model Parameters Common Across Countries

\begin{tabular}{|c|c|c|}
\hline Parameter & Expression & Value \\
\hline \multicolumn{3}{|l|}{ Preferences } \\
\hline Discount factor & $\beta$ & .98 \\
\hline Leisure weight & $\psi$ & 1.32 \\
\hline \multicolumn{3}{|l|}{ Growth rates $(\%)$} \\
\hline Population & $\gamma_{N}$ & 1.0 \\
\hline Technology & $\gamma_{A}$ & 1.2 \\
\hline \multicolumn{3}{|l|}{ Income shares (\%) } \\
\hline Technology capital & $\phi$ & 7.0 \\
\hline Tangible capital & $(1-\phi) \alpha_{T}$ & 21.4 \\
\hline Plant-specific intangible capital & $(1-\phi) \alpha_{I}$ & 6.5 \\
\hline Labor & $(1-\phi)\left(1-\alpha_{T}-\alpha_{I}\right)$ & 65.1 \\
\hline \multicolumn{3}{|l|}{ Nonbusiness sector $(\%)$} \\
\hline Fraction of time at work & $\bar{L}_{n b}$ & 6 \\
\hline Investment share & $\bar{X}_{n b} / \mathrm{GDP}$ & 15 \\
\hline Value-added share & $\bar{Y}_{n b} / \mathrm{GDP}$ & 31 \\
\hline \multicolumn{3}{|l|}{ Depreciation rates $(\%)$} \\
\hline Technology capital & $\delta_{M}$ & 8.0 \\
\hline Tangible capital & $\delta_{T}$ & 6.0 \\
\hline Plant-specific intangible capital & $\delta_{I}$ & 0 \\
\hline \multicolumn{3}{|l|}{ Tax rates $(\%)$} \\
\hline Labor wedge & $\tau_{l}$ & 34 \\
\hline Dividends & $\tau_{d}$ & 28 \\
\hline
\end{tabular}

Note.-Parameters are taken from McGrattan and Prescott's (2010) analysis of the U.S. current account. See

Holmes, McGrattan, and Prescott (2014) for a sensitivity analysis with respect to these parameter choices.

TABLE 3

Populations Relative to the United States, Selected Years

\begin{tabular}{lcccccc}
\hline \hline & China & U.S. & W. Europe & Japan & BRI & ROW \\
\hline 1990 & 465 & 100 & 151 & 49 & 469 & 172 \\
1995 & 463 & 100 & 144 & 47 & 479 & 175 \\
2000 & 458 & 100 & 138 & 45 & 487 & 177 \\
2005 & 451 & 100 & 136 & 43 & 497 & 182 \\
2010 & 442 & 100 & 133 & 41 & 505 & 185 \\
\hline \hline
\end{tabular}

NotE.- The source of these data is the World Bank, World Development Indicators database. Holmes, McGrattan, and Prescott (2014) report all years. 
TABLE 4

Estimated Paths for TFP and Degrees of Openness, Selected Years

\begin{tabular}{lcccccc}
\hline \hline & China & U.S. & W. Europe & Japan & BRI & ROW \\
\hline & & \multicolumn{5}{c}{ TFPs Relative to United States } \\
1990 & 13.5 & 100 & 80.5 & 92.4 & 20.0 & 34.0 \\
1995 & 16.3 & 100 & 80.6 & 89.2 & 20.0 & 35.2 \\
2000 & 20.3 & 100 & 80.6 & 88.0 & 20.1 & 36.4 \\
2005 & 24.5 & 100 & 80.7 & 88.0 & 21.5 & 37.6 \\
2010 & 27.8 & 100 & 80.7 & 88.0 & 21.7 & 38.6 \\
2015 & 29.7 & 100 & 80.8 & 88.0 & 21.7 & 39.5 \\
& & & Degree of Openness to FDI & & \\
1990 & .667 & .849 & .852 & .689 & .654 & .775 \\
1995 & .717 & .849 & .852 & .689 & .656 & .775 \\
2000 & .793 & .852 & .853 & .694 & .679 & .780 \\
2005 & .809 & .863 & .856 & .716 & .782 & .804 \\
2010 & .811 & .870 & .858 & .730 & .850 & .819 \\
2015 & .811 & .871 & .858 & .732 & .859 & .821 \\
\hline \hline
\end{tabular}

NotE.-See footnote for Table 5.

TABLE 5

Quid Pro Quo Costs, Selected Years

\begin{tabular}{lcccc}
\hline \hline & \multicolumn{2}{c}{ FDI of Advanced Countries } & & FDI of China \\
in China & in BRI & $\begin{array}{c}\text { FDI of BRI } \\
\text { in China }\end{array}$ \\
\hline 1990 & .002 & .006 & .011 & .003 \\
1995 & .010 & .009 & .008 & .010 \\
2000 & .026 & .012 & .008 & .023 \\
2005 & .038 & .022 & .016 & .031 \\
2010 & .044 & .036 & .029 & .037 \\
2015 & .045 & .039 & .035 & .041 \\
\hline \hline
\end{tabular}

NoTE.-Parameters governing TFPs, degrees of openness, and quid pro quo costs are chosen to align model and data trends for real GDP, inward FDI, and the share of FDI from advanced countries into China. Values for quid pro quo costs are indexed by source and host of FDI. In equilibrium, the differences between values in the case of FDI coming from the United States, Western Europe, and Japan are less than 1 percent, so we report only one value for China and one value for BRI. See text for details and Holmes, McGrattan, and Prescott (2014) for parameter values in all years. 
TABLE 6

Share of World Technology Capital (\%), Selected Years

\begin{tabular}{ccccccc}
\hline \hline & China & U.S. & W. Europe & Japan & BRI & ROW \\
\hline 1990 & 0.1 & 31.6 & 36.7 & 17.2 & 2.2 & 12.2 \\
1995 & 0.6 & 30.5 & 34.5 & 16.2 & 4.6 & 13.5 \\
2000 & 2.3 & 29.4 & 32.5 & 14.8 & 6.6 & 14.4 \\
2005 & 4.4 & 28.3 & 31.1 & 13.8 & 7.4 & 15.1 \\
2010 & 6.1 & 27.8 & 30.5 & 13.2 & 6.4 & 16.0 \\
\hline \hline
\end{tabular}

Note. - The share for country $i$ is $M_{i t}^{i} / \sum_{i} M_{i t}^{i}$.

TABLE 7

Ratio of Technology Capital to GDP in China and BRI, Selected Years

\begin{tabular}{ccccc}
\hline \hline & \multicolumn{2}{c}{ Technology Capital of China } & \multicolumn{2}{c}{ Technology Capital of BRI } \\
\cline { 2 - 5 } & Nontransferred & Transferred & Nontransferred & Transferred \\
\hline 1990 & 0.00 & 0.83 & 0.06 & 0.49 \\
1995 & 0.04 & 0.55 & 0.14 & 0.35 \\
2000 & 0.09 & 0.38 & 0.20 & 0.27 \\
2005 & 0.14 & 0.34 & 0.20 & 0.24 \\
2010 & 0.16 & 0.35 & 0.16 & 0.30 \\
\hline \hline
\end{tabular}

Note.- The nontransferred capital share for country $i$ is $M_{i t}^{i} / \mathrm{GDP}_{i t}$ and the transferred capital share is $\tilde{M}_{i t} / \mathrm{GDP}_{i t}$.

TABLE 8

Technology Capital of Advanced Countries in China and BRI, Selected Years

FDI in China

FDI in BRI

\begin{tabular}{cccc}
\hline $\begin{array}{c}\text { Multinationals' } \\
\text { Intensity } \\
\text { Level }\end{array}$ & $\begin{array}{c}\text { Share of } \\
\text { Technology Capital } \\
\text { Not Transferred }\end{array}$ & $\begin{array}{c}\text { Multinationals' } \\
\text { Intensity } \\
\text { Level }\end{array}$ & $\begin{array}{c}\text { Share of } \\
\text { Technology Capital } \\
\text { Not Transferred }\end{array}$ \\
\hline 0.21 & 0.79 & 0.29 & 0.79 \\
0.34 & 0.86 & 0.33 & 0.86 \\
0.41 & 0.86 & 0.35 & 0.88 \\
0.41 & 0.82 & 0.36 & 0.88 \\
0.35 & 0.77 & 0.33 & 0.84 \\
\hline
\end{tabular}

NOTE.-The intensity level for multinationals $j$ in country $i$ is equal to $q_{i t}^{j}$. In equilibrium, the differences between intensity levels of multinationals from the United States, Europe, and Japan are less than 1 percent, so we report only one value for China and one value for BRI and refer to these values as the intensity levels of the advanced countries. Technology capital not transferred is defined to be the ratio $\sum_{j} M_{i t}^{j} /\left(\tilde{M}_{i t}+\sum_{j} M_{i t}^{j}\right)$ where the sums over $j$ include only multinationals from the United States, Europe, and Japan. 
TABLE 9

Welfare Gains and Technology Capital Transfers, Arising from Policy Changes Starting 1991, 1990-2010

\begin{tabular}{|c|c|c|c|c|c|c|}
\hline & China & U.S. & W. Europe & Japan & BRI & ROW \\
\hline & \multicolumn{6}{|c|}{ A. China ends QPQ policy } \\
\hline Welfare gain $(\%)$ & 4.69 & -0.45 & -0.43 & -0.32 & -1.34 & -0.10 \\
\hline Nontransferred capital ratio & 0.43 & 0.96 & 0.94 & 0.92 & 1.11 & 1.02 \\
\hline \multirow[t]{2}{*}{ Total capital ratio } & 1.46 & 0.96 & 0.94 & 0.92 & 0.95 & 1.02 \\
\hline & \multicolumn{6}{|c|}{ B. China and BRI both end QPQ policy } \\
\hline Welfare gain (\%) & 4.37 & -0.96 & -0.92 & -0.75 & 4.61 & -0.28 \\
\hline Nontransferred capital ratio & 0.44 & 0.92 & 0.90 & 0.87 & 0.54 & 1.04 \\
\hline \multirow[t]{2}{*}{ Total capital ratio } & 1.48 & 0.92 & 0.90 & 0.87 & 1.36 & 1.04 \\
\hline & \multicolumn{6}{|c|}{ C. China stops taxing profits of advanced countries } \\
\hline Welfare gain $(\%)$ & 0.99 & -0.18 & -0.18 & -0.08 & -0.14 & -0.05 \\
\hline Nontransferred capital ratio & 1.04 & 0.97 & 0.97 & 0.96 & 1.05 & 1.01 \\
\hline \multirow[t]{2}{*}{ Total capital ratio } & 1.02 & 0.97 & 0.97 & 0.96 & 1.00 & 1.01 \\
\hline & \multicolumn{6}{|c|}{ D. Advanced countries all implement QPQ policy } \\
\hline Welfare gain $(\%)$ & 1.98 & -0.74 & -0.64 & -8.57 & 2.30 & 0.09 \\
\hline Nontransferred capital ratio & 0.79 & 1.25 & 1.33 & 6.13 & 0.88 & 0.91 \\
\hline Total capital ratio & 1.14 & 0.90 & 0.96 & 0.89 & 1.17 & 0.91 \\
\hline
\end{tabular}

NOTE.-The welfare gains are the percentage increase in paths of consumption necessary for households in a specified country to be indifferent between having the new policy listed in Panels A through D versus its actual policies. The capital ratios are ratios of the nontransferred capital and total (transferred plus nontransferred) capital stocks in 2010 for each country, with the numerators equal to the stocks consistent with the policies China actually followed, and the denominators equal to the stocks consistent with the counterfactual policies. Advanced countries are United States, Western Europe, and Japan. 
TABLE 10

Results for Alternative Model Specifications

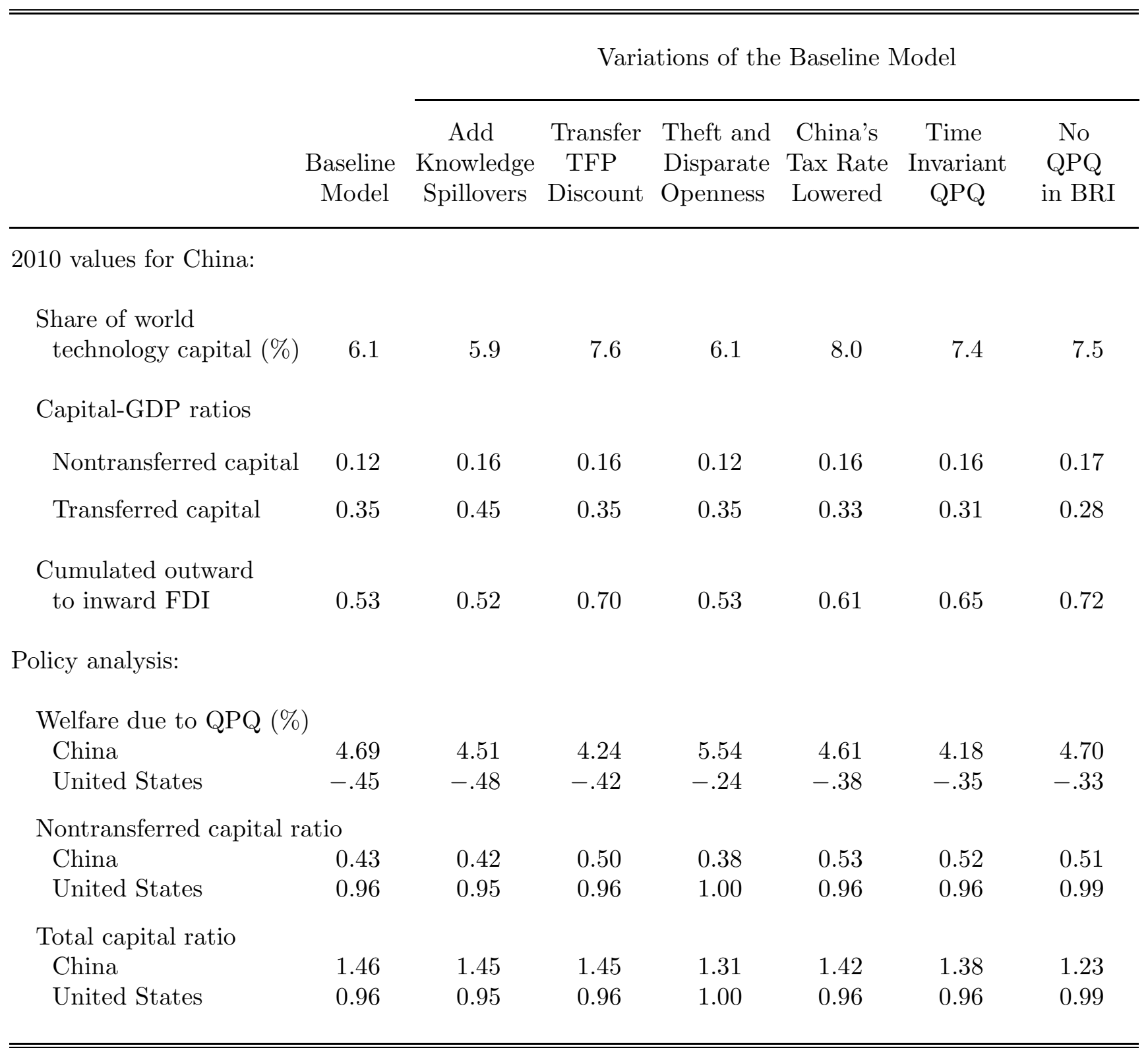

Note.-Results for the baseline model are also shown in Tables 6-9 and Figure 6. The experiments are as follows: "Add Knowledge Spillovers" has $g(\mu)>1$ for all countries; "Transfer TFP Discount" has $\zeta=0.9$; "Theft and Disparate Openness" is isomorphic to the baseline model but in the counterfactual experiment the intensity levels are held fixed at their baseline values; "China's Tax Rate Lowered" assumes that China's corporate profits tax rate falls from 33 percent to 25 percent, with most of the decline occurring between 2005 and 2009; "Time Invariant QPQ" has a quid pro quo cost function that is not time-varying; and "No QPQ in BRI" has $h_{\mathrm{BRI}, t}^{j}(q)$ for all $j$. The same procedure for choosing parameters in the baseline model is applied in all variations of the baseline. See Section 5.1 for details and Holmes, McGrattan, and Prescott (2014) for a list of all parameter inputs. 


\section{Figure 1. Inward Foreign Direct Investment to China ${ }^{a}$}

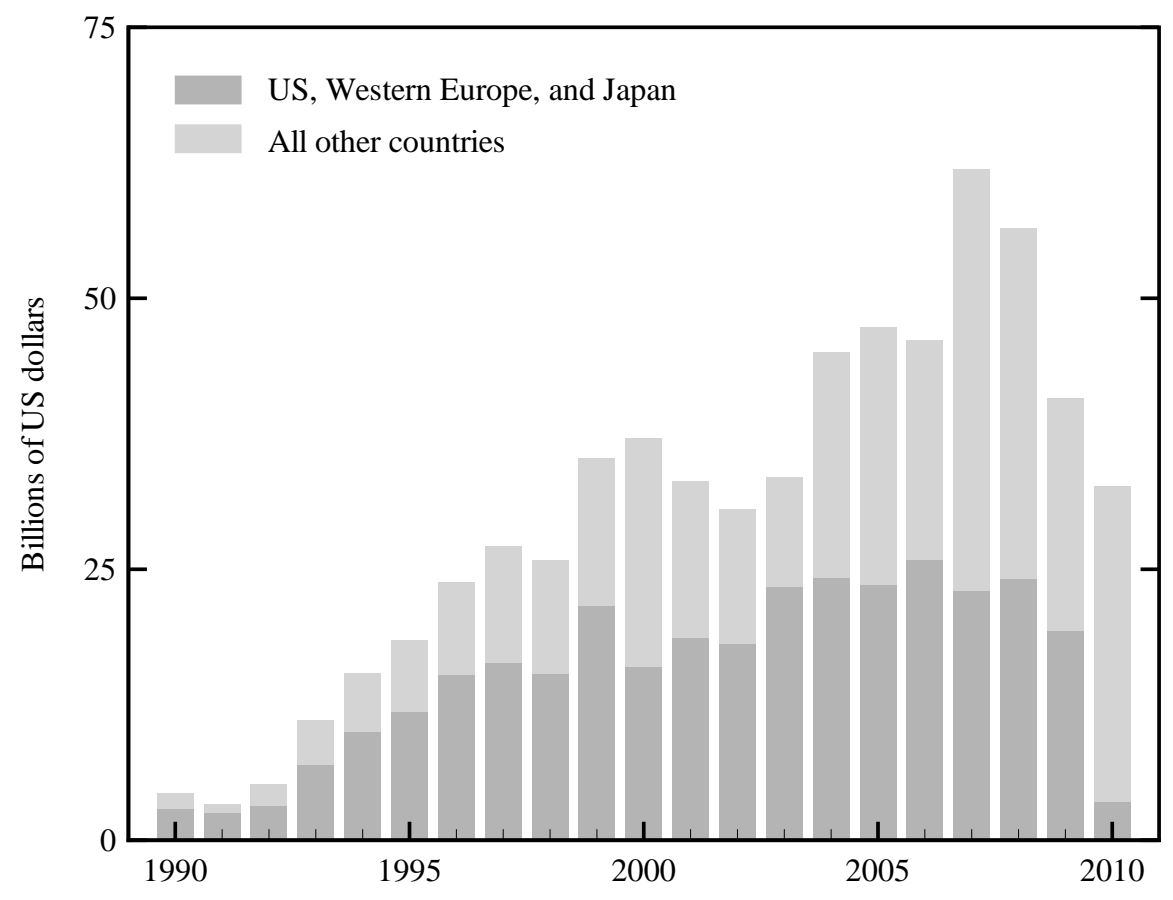

Figure 2. Outward Foreign Direct Investment from China ${ }^{a}$

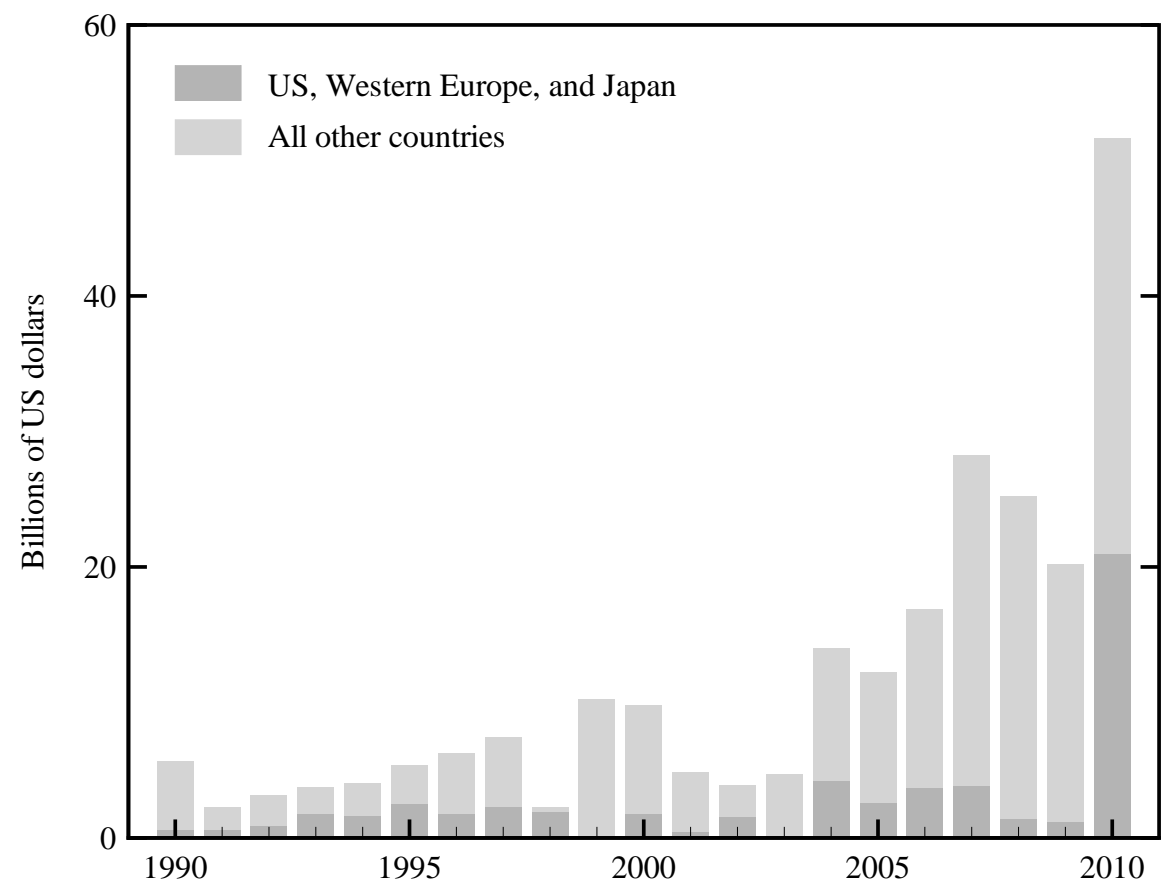

${ }^{a}$ Includes inward and outward flows to Hong Kong, Taiwan, and Macao with intraprovincial flows netted. Excludes flows to and from the British Virgin Islands and Cayman Islands. 
Figure 3. Real Per Capita GDP Relative to United States

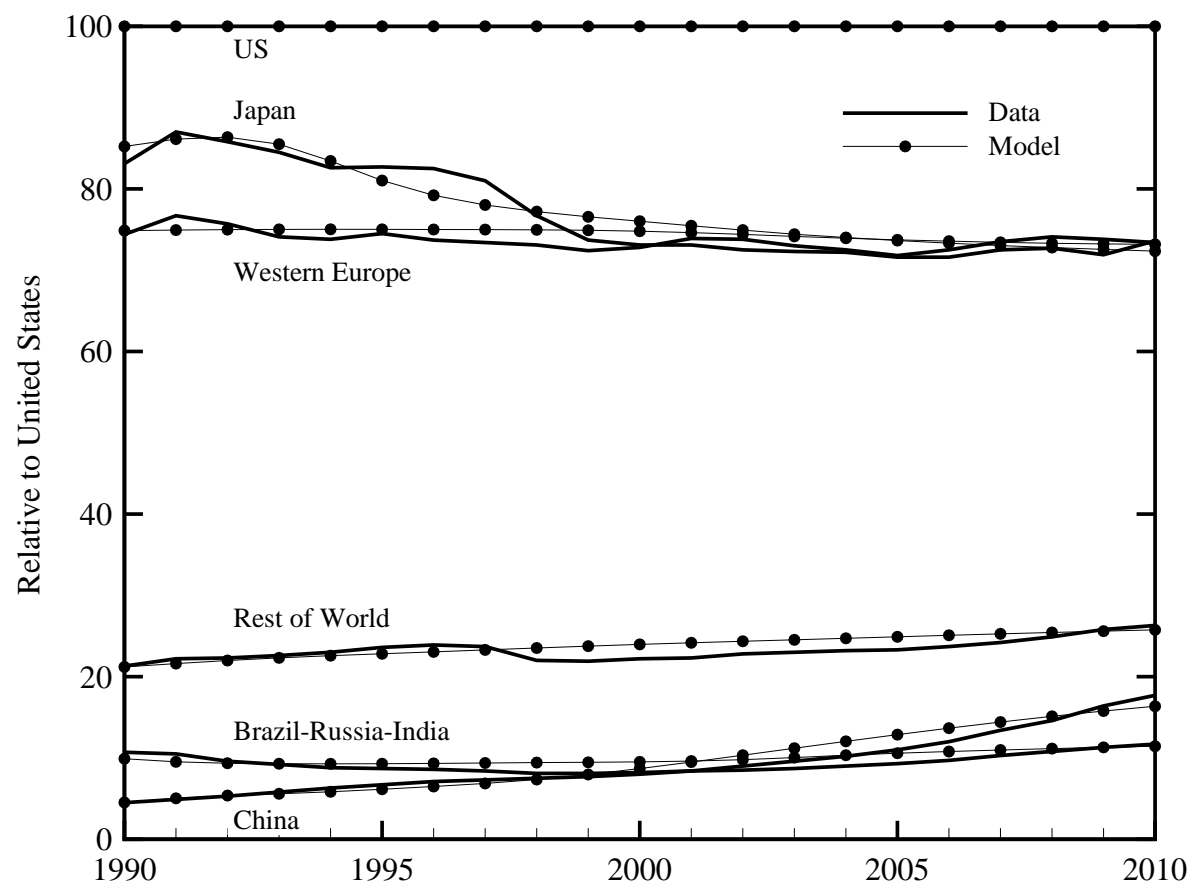

Figure 4. Cumulative Inward FDi Relative to Trend GDP, Normalized by 2010 Estimate for China

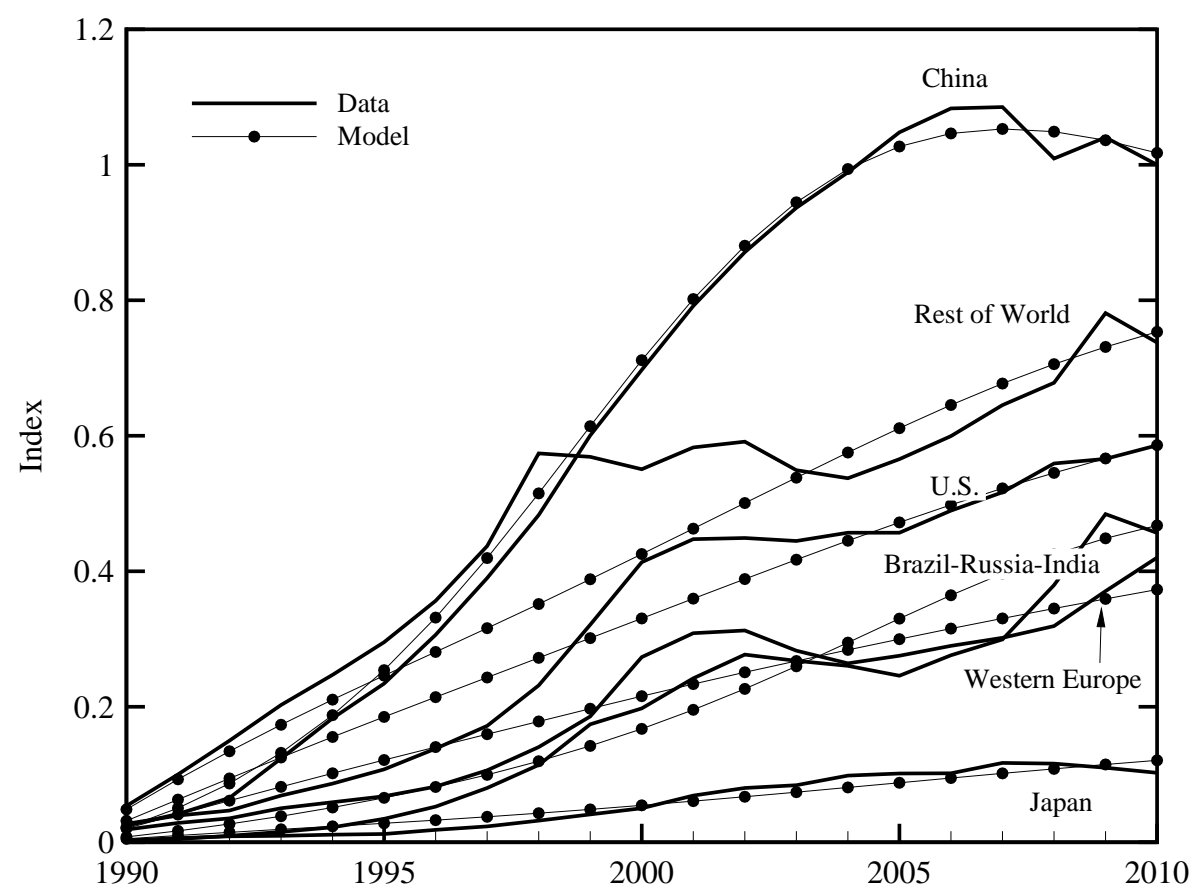


Figure 5. Share of InWard FDI to China from the

United States, Western Europe, and Japan

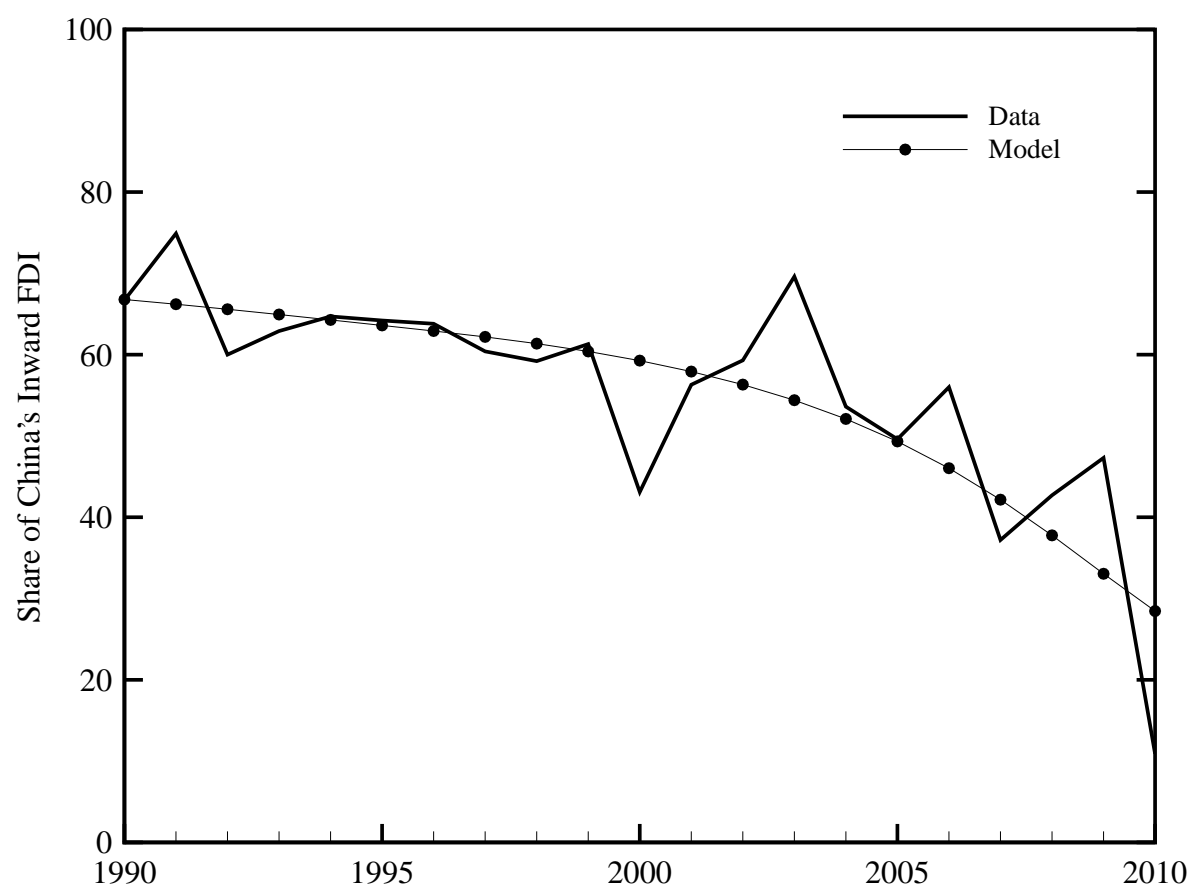

Figure 6. Cumulative Outward FDi Relative to Trend GDP, Normalized by 2010 Estimate of Inward FDI to China

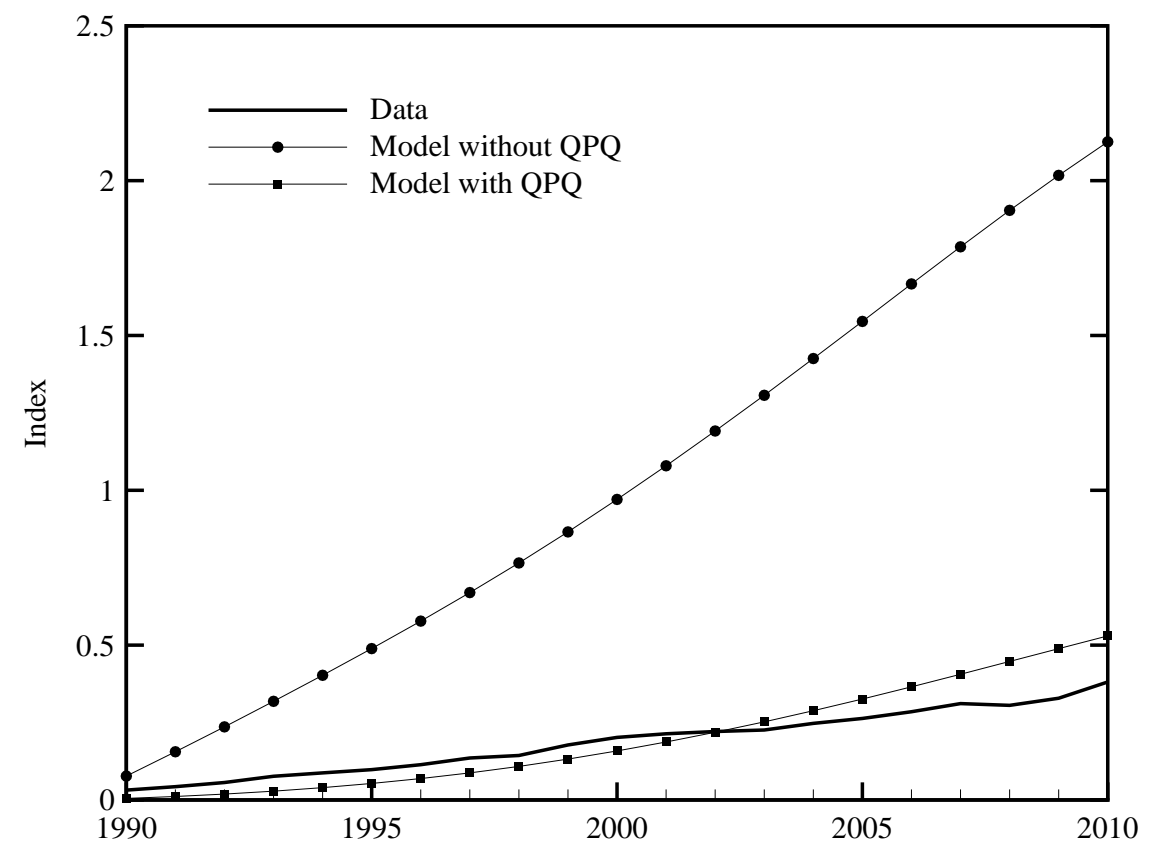

